\title{
The Complete Amino Acid Sequence of the $\mathrm{Zn}^{2+}$-Containing D-Alanyl-D-Alanine-Cleaving Carboxypeptidase of Streptomyces albus $\mathbf{G}$
}

Bernard JORIS, Jozef VAN BEEUMEN, Fabiana CASAGRANDE, Charles GERDAY, Jean-Marie FRĖE, and Jean-Marie GHUYSEN

Service de Microbiologie, Institut de Chimie, Université de Liège au Sart Tilman, Liège;

Laboratorium voor Microbiologie en microbiele Genetica, Rijksuniversiteit-Gent, Gent; and

Service de Biochimie musculaire, Institut de Chimie, Université de Liège au Sart Tilman, Liège

(Received July 30/September 28, 1982) - EJB 5847

The 22076- $M_{\mathrm{r}} \mathrm{Zn}^{2+}$-containing D-alanyl-D-alanine-cleaving carboxypeptidase of Streptomyces abuls G effectively catalyses the transfer of the $N^{\alpha}, N^{\varepsilon}$-diacetyl-L-lysyl-D-alanyl electrophilic group of the standard tripeptide substrate $N^{\alpha}, N^{\varepsilon}$-diacetyl-L-lysyl-D-alanyl-D-alanine to water. It also performs a weak $\beta$-lactamase activity, hydrolysing penicillin into penicilloate at a very low rate. This protein consists of 212 amino acid residues in a single polypeptide chain. The $\mathrm{N}$ terminus is partially blocked as a result of the cyclization of the dipeptide Asn-Gly into anhydroaspartylglycine imide. The protein has been fragmented by cyanogen bromide into five fragments whose sequences have been determined via appropriate subcleavages with various proteases. The ordering of the cyanogen bromide peptide fragments has been carried out (a) by submitting the $S$-carboxymethylated protein to complete tryptic digestion and labelling the methionine-containing peptides thus obtained with iodo $\left[{ }^{14} \mathrm{C}\right]-$ acetamide, and (b) by submitting to limited tryptic digestion the $S$ - $22-\left(4^{\prime}\right.$-pyridyl)ethyl]-cysteine protein whose amino groups have been blocked by reaction with exo-cis-3,6-endoxo- $\Delta^{4}$-tetrahydrophthalic anhydride prior to digestion. The protein contains six cysteine residues in the form of three disulfide bridges. No homology is found by comparing this peptidase with other $\mathrm{Zn}^{2+}$-containing enzymes (carboxypeptidase $\mathrm{A}$, thermolysin, carbonic anhydrase $\mathrm{B}$ and alcohol dehydrogenase) and several completely or partially sequenced, serine-containing D-alanyl-D-alanine-cleaving peptidases and $\mathrm{Zn}^{2+} /$ serine-containing $\beta$-lactamases.

The D-alanyl-D-alanine-cleaving peptidases (in short DDpeptidases) are enzymes involved in the bacterial wall peptidoglycan metabolism. They catalyse transfer of LAla-DGlu(LRaa-DAla) (where DGlu is a $\gamma$-glutamyl residue and Raa is a diamino acid or an amino acid grouping possessing a free $\omega$-amino group) from LAla-DGlu(LRaa-DAla-DAla) pentapeptide units either to water (carboxypeptidation) or to the $\omega$-amino group at the L-Raa position of another peptide (transpeptidation). On the basis that the sequence LRaa-DAlaDAla is that part of the carbonyl donor mainly involved in substrate activity, the tripeptide $N^{\alpha}, N^{\varepsilon}$-diacetyl-L-lysyl-Dalanyl-D-alanine ( $\mathrm{Ac}_{2}$ LLys-DAla-DAla) has been used as a substrate analogue to isolate several DD-peptidases exhibiting, with varying efficiencies, carboxypeptidase activity $\left(\mathrm{Ac}_{2}-\right.$ LLys-DAla-DAla $+\mathrm{H}_{2} \mathrm{O} \rightarrow$ DAla $+\mathrm{Ac}_{2}$ LLys-DAla) and/or transpeptidase activity ( $\mathrm{Ac}_{2}$ LLys-DAla-DAla + a suitable amino compound $\mathrm{NH}_{2}-\mathrm{X} \rightarrow \mathrm{DAla}+\mathrm{Ac}_{2}$ LLys-DAla-CONH$\mathrm{X})$ (for a recent review, see [1]). The R61 (from Streptomyces

Abbreviations. Cya, cysteic acid; CmCys, $S$-carboxymethyl-cysteine; PeCys, $S$-[2-(4'-pyridyl)ethyl]cysteine; SCM-protein, protein treated with iodoacetic acid giving rise to $\mathrm{CmCys}$ residues; $\mathrm{SPE}$-protein, protein treated with 4-vinyl-pyridine giving rise to PeCys residues; DABITC, 4- $N, N$-dimethylaminoazobenzene-4'-isothiocyanate; PITC, phenylisothiocyanate; dansyl and Dns, 5-dimethylaminonaphthalene-1-sulfonyl; $\mathrm{Nbs}_{2}$, 5,5'-dithio-bis(2-nitrobenzoic acid); ETPA, exo-cis-3,6-endoxo$\Delta^{4}$-tetrahydrophthalic anhydride; EtSH, 2-mercaptoethanol; Hse, homoserine; $\mathrm{MetO}_{2}$, methionine sulfone; HPLC, high-performance liquid chromatography; SDS, sodium dodecyl sulfate.

Enzymes. D-Alanyl-D-alanine-cleaving carboxypeptidase or DD-peptidase (EC 3.4.17.8); Armillaria mellea protease (EC 3.4.99.32); carboxypeptidase Y (EC 3.4.16.1); chymotrypsin (EC 3.4.21.1); pepsin (EC 3.4.23.1); Staphylococcus aureus V8 protease (EC 3.4.21.19); thermolysin (EC 3.4.24.4); trypsin (EC 3.4.21.4).
R61) and R39 (from Actinomadura R39) DD-peptidases are highly penicillin-sensitive, bifunctional carboxypeptidases/ transpeptidases. They operate by covalent catalysis via an active serine residue. In contrast, the G (from Streptomyces albus $\mathrm{G})$ DD-peptidase is a highly penicillin-resistant, monofunctional carboxypeptidase. It operates by liganding catalysis via a $\mathrm{Zn}^{2+}$ cofactor which is firmly bound to the apoprotein $\left(K_{\mathrm{A}}: 2 \times 10^{14} \mathrm{M}^{-1}\right)$ [2]. On the basis of $\mathrm{X}$-ray crystallographic studies [3], this $\mathrm{G} \mathrm{Zn}^{2+}$ DD-carboxypeptidase is a two-domain protein. A cleft, with the $\mathrm{Zn}^{2+}$ cofactor located in it, extends throughout the large domain and serves as binding site for the two enzyme competitive inhibitors, the dipeptide AcDAla-DGlu and the $\beta$-lactam compound $p$-iodo7- $\beta$-phenylacetylaminocephalosporanic acid. The interpretation of the $2.5-\AA(0.25-\mathrm{nm})$ electron density map of the $G$ $\mathrm{Zn}^{2+}$ DD-carboxypeptidase has been carried out simultaneously with the establishment of its primary structure. This paper is the first report of the complete amino acid sequence of a member of this special class of bacterial DD-peptidases that characterize themselves by their ability specifically to attack peptide bonds extending between two D centres.

\section{MATERIALS AND METHODS}

\section{Preparation of the DD-Peptidase (Native Protein)}

The DD-peptidase was isolated and purified to protein homogeneity as described in [4].

\section{Reduced and Alkylated Protein}

After unfolding the protein in $6 \mathrm{M}$ guanidinium chloride and cleavage of the S-S bridges with dithiothreitol, alkylation 
of the SH groups in the reduced protein was carried out by treatment with iodoacetic acid, giving rise to $S$-carboxymethyl cysteine (CmCys) residues (SCM-protein), [5] or 4 -vinyl-pyridine, giving rise to $S$-[2-(4'-pyridyl)ethyl]cysteine (PeCys) residues (SPE-protein) [6]. The efficacy of each of the treatments was checked by amino acid analysis to detect cystic acid (Cya) after further performic acid oxidation [7] of the reduced and alkylated protein.

\section{Proteolvtic Enzymes}

Trypsin (treated with L-1-tosylamido-2-phenylethyl chloromethyl ketone) and chymotrypsin were from Worthington (Freehold, NJ, USA). Carboxypeptidase $\mathrm{Y}$ and pepsin were from Boehringer (Mannheim, FRG). Thermolysin was from Calbiochem (San Diego, CA, USA) and Staphylococcus aureus protease V8 from Miles (Slough, England). Armillaria mellea protease was a gift from Dr V. Barkholt Pedersen (Copenhagen, Denmark)

\section{Chemicals}

Analytical grade reagents were used. Cyanogen bromide and 4-vinyl-pyridine were from Aldrich-Europe (Beerse, Belgium). Mercaptoethanesulfonic acid and anhydrous hydrazine were from Pierce Chemicals Co. (Rockford, IL, USA). Fluorescamine was from Fluka (Buchs, Switzerland), 5,5'dithio-bis(2-nitrobenzoic acid) $\left(\mathrm{Nbs}_{2}\right)$ from Sigma (St Louis, MO, USA), and iodo $\left[{ }^{14} \mathrm{C}\right]$ acetamide $(50 \mathrm{Ci} / \mathrm{mol})$ from New England Nuclear (Dreieich, FRG). Exo-cis-3,6-endoxo- $\Delta^{4}$ tetrahydrophtalic anhydride (ETPA) was synthesized as described by Riley et al. [8]. All the other chemicals were from Merck (Darmstadt, FRG).

\section{Thin-Layer Sheets, Chromatography and Electrophoresis Papers}

Polyamide-coated thin-layer sheets (F1700) were either from Pierce Chemicals Co. or from Schleicher \& Schüll (Dassel, FRG). Chromatography and electrophoresis papers were from Whatman (Maidstone, Kent, UK).

\section{Solvents and Reagents}

\section{for Manual Amino Acid Sequencing}

1-Dimethylaminonaphtalene-5-sulphonyl (dansyl) chloride was from BDH (Poole, England). Phenylisothiocyanate (PITC), 4-N,N-dimethylaminoazobenzene-4'-isothiocyanate (DABITC) and trifluoroacetic acid were from Pierce Chemicals Co. Pyridine (analytical grade from Merck) was purified by two successive distillations, first over ninhydrin (20 g/l) and then over $\mathrm{KOH}$ pellets under nitrogen. Butyl acetate was distilled over ninhydrin $(10 \mathrm{~g} / \mathrm{l})$. Heptane and ethyl acetate were spectroscopic grade reagents from Merck.

\section{Solvents and Reagents}

for Automatic Liquid Amino Acid Sequencing and High-Performance Liquid Chromatography (HPLC)

The solvents and reagents used in the sequenator were 'sequenal grade' and were not purified further. The compounds $1 \mathrm{M}$ quadrol, $n$-propanol (used to dilute the quadrol to a $0.3 \mathrm{M}$ concentration), benzene, ethyl acetate and chlorobutane were from Merck. Hexafluorobutyric acid was from Pierce and trifluoroacetic acid was from Rathburn (Scotland). The dithiothreitol added to the chlorobutane to a final concentration of $0.001 \%$ was from Calbiochem. The acetonitrile used in the HPLC analysis of the phenylhydantoins was Lichrosolv grade from Merck. The HPLC water was from Alltech Assoc. (IL, USA).

\section{Amino Acid Analysis}

Protein samples $(40 \mathrm{nmol})$ were hydrolyzed under vacuum in $150 \mu \mathrm{l}$ of $6 \mathrm{M} \mathrm{HCl}$ at $110^{\circ} \mathrm{C}$ for $24 \mathrm{~h}, 48 \mathrm{~h}$ and $72 \mathrm{~h}$ and analysed with a Beckman 120B analyser. Peptide samples $(5-30 \mathrm{nmol})$ were hydrolyzed for $24 \mathrm{~h}$ under the same conditions and analysed with a Beckman Multichrom 4255 or a Dionex D300. Cysteine and methionine were determined as $\mathrm{Cya}$ and methionine sulfone $\left(\mathrm{MetO}_{2}\right)$ after performic oxidation of the protein [7]. Tryptophan was estimated after hydrolysis with $3 \mathrm{M}$ mercaptoethane sulfonic acid for $96 \mathrm{~h}$ at $110^{\circ} \mathrm{C}[9]$.

\section{Determination of the $N$-Terminal Residues}

Dansyl chloride was used according to the procedure recommended for the proteins by Gray [10]. For peptide fragments, the determination of the $\mathrm{N}$-terminal residues was carried out by the method of Hartley [11].

\section{Determination of the C-Terminal Residues}

Samples $(1 \mathrm{mg})$ of SCM-protein and of peptide $\mathrm{CB}_{3}$ (obtained by cyanogen bromide cleavage of the protein) were treated with $0.5 \mathrm{ml}$ anhydrous hydrazine for $24 \mathrm{~h}$ at $80^{\circ} \mathrm{C}$. Each hydrazinolysate was dried under vacuum over concentrated sulphuric acid, and the residue was dissolved in $0.5 \mathrm{ml}$ $\mathrm{H}_{2} \mathrm{O}$. The solution was adjusted to $\mathrm{pH} 3$ with $6 \mathrm{M} \mathrm{HCl}$ and filtered in water on a column $(0.9 \times 11 \mathrm{~cm})$ of Amberlite IRC50 $\left(\mathrm{H}^{+}\right.$form $)$. The first $15 \mathrm{ml}$ of the eluent were collected and, after freeze-drying, the residue was submitted to an additional chromatography under the same conditions as above (in order to remove all the hydrazides). The free amino acid residue released by hydrazinolysis was then identified with the amino acid autoanalyser.

\section{Sequence Determination}

The SCM-protein $(100 \mathrm{nmol})$ and large-size peptides $(100 \mathrm{nmol})$ were submitted to automatic liquid-phase Edman degradation [12] in a Socosi 110 sequenator (Saint-Maure, France), using $0.3 \mathrm{M}$ quadrol as coupling buffer and $2 \mathrm{mg}$ of polybrene [13] as carrier. The thiazolinones were converted manually using $20 \%$ trifluoroacetic acid [14] for $25 \mathrm{~min}$ at $55^{\circ} \mathrm{C}$. The phenylthiohydantoins were analysed by 'reversedphase' HPLC on a column $(0.46 \times 30 \mathrm{~cm})$ of $\mathrm{C} 18 \mathrm{HL}$ RSil (RSL, Eke, Belgium) using either an isochratic [15] or a gradient [16] elution method with acetonitrile as the organic solvent.

Small-size peptides $(5-50 \mathrm{nmol})$ were sequenced manually, following the micro dansyl-Edman [17] or the DABITC PITC [18] method. In some cases where the presence of amides or tryptophan residues was expected and when the initial degradation with the DABITC/PITC method resulted in a severe wash-out of the residual peptides, a combination of the two methods was used. In those cases, the first N-terminal residues were cleaved by the dansyl-Edman method without removing samples for dansylation and the following degradation steps were carried out by the DABITC/PITC 
method. All the peptides were sequenced in 1-ml conic vials closed with a teflon septum.

\section{Estimation of the SH Groups}

Quantitative estimation was carried out spectrophotometrically as described in [19], using $\mathrm{NBs}_{2}$ as reagent. Either sodium dodecylsulfate (SDS) $(4 \%$ w/v) or a mixture of $6 \mathrm{M}$ guanidinium chloride and $2 \mathrm{mM}$ EDTA were used as denaturing agents. Glutathione served as control.

\section{Estimation of Sugars and S-Glyceryl-cysteine Thioether in the Native Protein}

The possible occurrence of a carbohydrate moiety in the protein was tested by using the method of Dubois [20] and that of $S$-glyceryl-cysteine was tested as described in [21], except that the quantities and volumes were divided by 10 .

\section{Cyanogen Bromide Cleavage of the SCM-Protein}

A solution of the SCM-protein $(10 \mathrm{mg} / \mathrm{ml})$ made in $70 \%$ formic acid was supplemented with cyanogen bromide (40 $\mathrm{mg} / \mathrm{ml}$, final concentration), left in the dark for $24 \mathrm{~h}$ at room temperature under nitrogen and finally freeze-dried.

Purification of the Cyanogen Bromide Peptide Fragments CB2, $C B 3, C B 4, C B 5$ and $C B 6$

Two procedures were used (see flow sheet in Fig. 1). In a first experiment and as shown in Fig. $1 \mathrm{M}$ (M refers to the miniprint section), the soluble peptides originating from $5 \mu \mathrm{mol}$ of SCM-protein (and separated from an insoluble core) were fractionated by filtration on a column $(2.5 \times 150 \mathrm{~cm})$ of Sephadex G-50, fine, in $0.2 \mathrm{M} \mathrm{NH}_{4} \mathrm{HCO}_{3}$ buffer $\mathrm{pH} 8.6$ (flow rate $35 \mathrm{ml} / \mathrm{h}$; volume of the fractions $5.3 \mathrm{ml}$; manual detection at 280 and $214 \mathrm{~nm}$ ). Fraction CB1 was the uncleaved protein. Peptide CB2 (115 residues) and peptide CB3 (58 residues) were obtained in pure form. Peptides CB5 and CB6 (5 and 4 residues, respectively) were recovered in the salt volume and further isolated from each other by paper electrophoresis at $\mathrm{pH} 3.5$. In a second experiment and as shown in Fig. $2 \mathrm{M}$, all the peptide fragments originating from $0.8 \mu \mathrm{mol}$ of SCM-protein were solubilized in $50 \mathrm{mM}$ ammonium formate buffer $\mathrm{pH} 3.5$ supplemented with $2 \mathrm{M}$ guanidinium chloride. Filtration of the solution on a column $(1.25 \times 150 \mathrm{~cm})$ of Sephadex G-50 fine in $50 \mathrm{mM}$ ammonium formate buffer $\mathrm{pH} 3.5$ (flow rate $15 \mathrm{ml} / \mathrm{h}$; volume of the fractions $1.2 \mathrm{ml}$; detection at $230 \mathrm{~nm}$ ) resulted in the isolation of an additional peptide CB4 (29 residues) which coeluted with peptide CB3. Complete separation of $\mathrm{CB} 3$ and $\mathrm{CB} 4$ from each other was achieved by paper electrophoresis at $\mathrm{pH} 6.5$ (pyridine/glacial acetic acid/water; $100 / 4 / 900 ; \mathrm{v} / \mathrm{v} / \mathrm{v}$ ).

\section{Enzymatic Cleavage of the Cyanogen Bromide Peptide}

Fragments $C B 2, C B 3$ and $C B 4$, and Isolation of the Digested Peptides

$\mathrm{CB} 2, \mathrm{CB} 3$ and CB4 were digested as indicated in the flow sheet (Fig. 1) and under the conditions given in Table 1. The digested samples were freeze-dried. The large peptides $(\geq 30$ residues) were first filtered on Sephadex using, depending on the samples, columns of varying sizes $(1 \times 100 \mathrm{~cm}$, or $1 \times 150 \mathrm{~cm}$ ), Sephadex G-25 fine or Sephadex G-50 fine, and $5 \%$ formic acid or $50 \mathrm{mM}$ ammonium formate buffer, $\mathrm{pH} 3.5$,

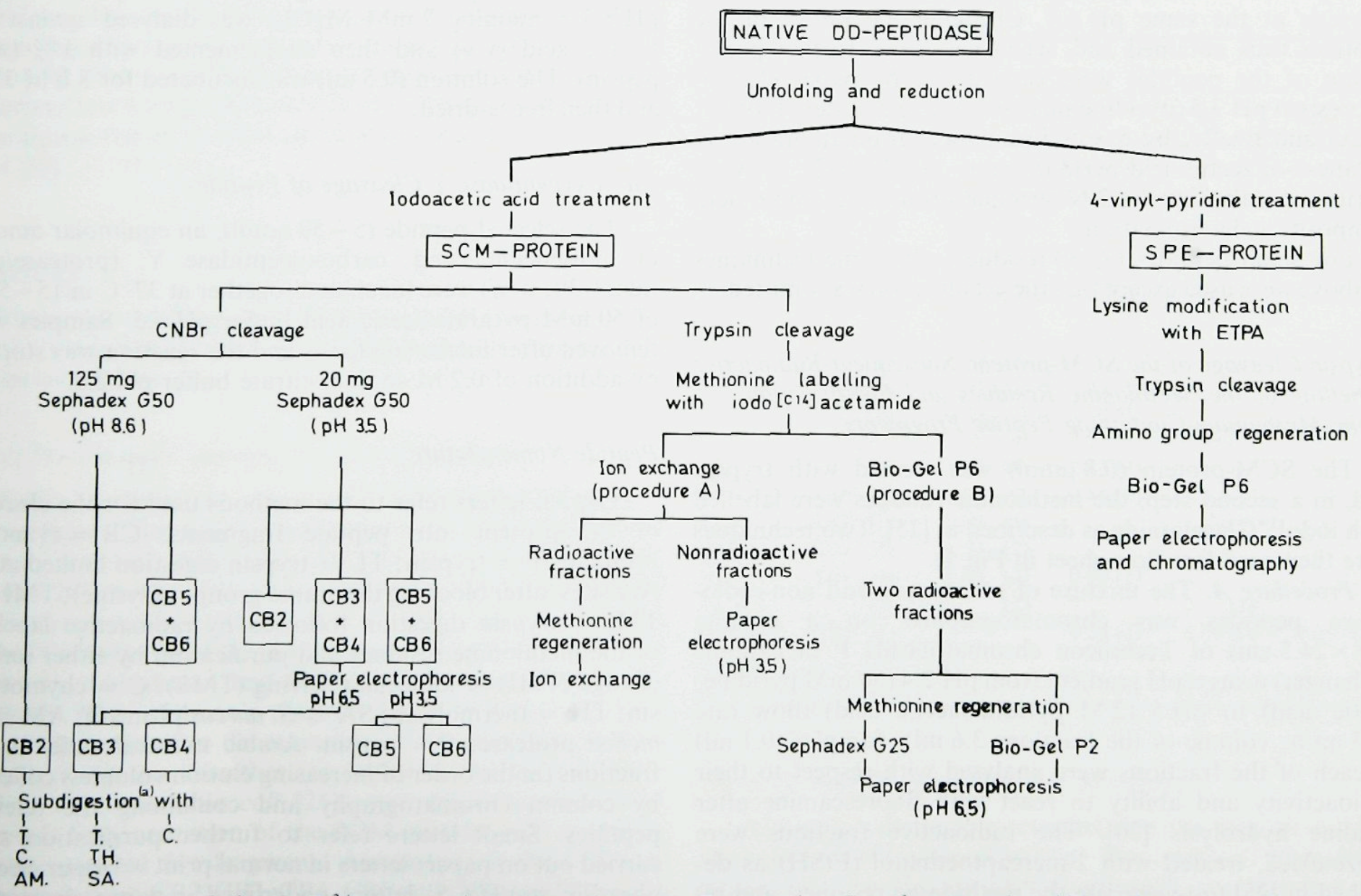

Fig. 1. Fragmentation of the $G \mathrm{Zn}^{2+}$ DD-peptidase. Flow sheet. (a) $\mathrm{T}=$ trypsin; $\mathrm{C}=$ chymotrypsin; AM = Armillaria mellea protease; $\mathrm{TH}=$ thermolysin $; \mathrm{SA}=$ Staphylococcus aureus protease 
Table 1. Enzmmatic digestion of the peprides obrained after CNBr cleavage of the SCM-protein

Buffers: (a) $0.2 \mathrm{M}$ ammonium acetate $\mathrm{pH} 8.5$; (b) $0.1 \mathrm{M} \mathrm{N}$-ethylmorpholine acetate pH 8.0 ; (c) $0.1 \mathrm{M}$ ammonium bicarbonate $\mathrm{pH} 7.8$ containing $2 \mathrm{mM}$ EDTA

\begin{tabular}{|c|c|c|c|c|}
\hline Protease & $\begin{array}{l}\text { Peptide } \\
\text { concen- } \\
\text { tration }\end{array}$ & $\begin{array}{l}\text { Protease } \\
\text { peptide } \\
(w / w)\end{array}$ & Buffer & $\begin{array}{l}\text { Duration of the } \\
\text { incubation at } \\
37^{\circ} \mathrm{C} \text { (unless } \\
\text { otherwise } \\
\text { stated) }\end{array}$ \\
\hline
\end{tabular}

\begin{tabular}{|c|c|c|c|c|}
\hline & $\mathrm{mg} / \mathrm{ml}$ & & & $\mathrm{h}$ \\
\hline Trypsin & 10 & $1 / 40$ & $\mathrm{a}$ & 2 \\
\hline Chymotrypsin & 10 & $1 / 40$ & $\mathrm{a}$ & 1 or 2 \\
\hline $\begin{array}{l}\text { Thermolysin } \\
\text { S. aureus }\end{array}$ & 10 & $1 / 100$ & $\mathrm{~b}$ & $1\left(50^{\circ} \mathrm{C}\right)$ \\
\hline $\begin{array}{l}\text { protease } \\
\text { A. mellea }\end{array}$ & 1.3 to 2.5 & 150 & c & 4 or 16 \\
\hline protease & 7 & $1 / 3000$ & $\mathrm{~b}$ & 6.5 \\
\hline
\end{tabular}

as eluants (flow rate $20 \mathrm{ml} / \mathrm{h}$; size of the fractions $1.5 \mathrm{ml}$ ). Detection was made with a Uvicord II at $280 \mathrm{~nm}$ (in the presence of formic acid) or manually at $230 \mathrm{~nm}$ (in the presence of ammonium formate). In all cases, samples of the collected fractions were spotted along the same base line $(0.5 \mathrm{~cm}$ for each fraction) on a Whatman $3 \mathrm{MM}$ paper and submitted to electrophoresis at $\mathrm{pH}$ 6.5. Detection of the peptides was made by successive staining with fluorescamine $(0.001 \%$ in dry acetone) [22], ninhydrin/acetic acid/acetone $(0.25 / 1 / 99 ; \mathrm{w} / \mathrm{v} / \mathrm{v})[23]$ and Pauly's reagent as described in [24]. On the basis of the maps thus obtained, the relevant fractions were pooled and then purified by preparative paper electrophoresis at the same $\mathrm{pH} 6.5$. Checking the purity of the peptides thus obtained and, when necessary, further purification of the peptides were carried out by paper electrophoresis at pH 3.5 (pyridine/glacial acetic acid/water; 1/10/89; $\mathrm{v} / \mathrm{v} / \mathrm{v}$ ) and finally, by descending paper chromatography in butane-1-ol acetic acid/pyridine/water $(15 / 3 / 10 / 12 ; \mathrm{v} / \mathrm{v} / \mathrm{v} / \mathrm{v})$. Purity tests also involved N-terminal group and amino acid composition determinations.

For small peptides ( $\leq 30$ residues), the same techniques as above were used except that the gel filtration was omitted.

Trypsin Cleavage of the SCM-protein, Subsequent Radioactive Labelling of the Methionine Residues and Identification of the Methionine-Containing Peptide Fragments

The SCM-protein $(0.8 \mu \mathrm{mol})$ was treated with trypsin and, in a second step, the methionine residues were labelled with iodo $\left[{ }^{14} \mathrm{C}\right]$ acetamide as described in [25]. Two techniques were then used (see flow sheet in Fig. 1).

Procedure $A$. The mixture of radioactive and non-radioactive peptides was chromatographed on a column $(0.8 \times 24.5 \mathrm{~cm})$ of Technicon chromatobeads $\mathrm{P}$ (a cationic exchanger) using a $\mathrm{pH}$ gradient from $\mathrm{pH} 2.4(50 \mathrm{mM}$ pyridine/ acetic acid) to $\mathrm{pH} 5$ ( $2 \mathrm{M}$ pyridine/acetic acid) (flow rate $16.3 \mathrm{ml} / \mathrm{h}$; volume of the fractions $3.6 \mathrm{ml})$. Samples $(0.1 \mathrm{ml})$ of each of the fractions were analysed with respect to their radioactivity and ability to react with fluorescamine after alkaline hydrolysis [26]. The radioactive fractions were freeze-dried, treated with 2-mercaptoethanol (EtSH) as described in [25] to regenerate the methionine residues, and rechromatographed under the same conditions as above.
Procedure $B$. Filtration of the mixture of radioactive and nonradioactive peptides on a column $(1.15 \times 140 \mathrm{~cm})$ of BioGel P6 (200 mesh) in $50 \mathrm{mM}$ ammonium formate buffer, $\mathrm{pH} 3.5$ (flow rate $9.8 \mathrm{ml} / \mathrm{h}$; volume of the fractions $1.1 \mathrm{ml}$ ) yielded two radioactive fractions. Each of these fractions was freezedried, treated with EtSH and, depending on the size of the peptides to be purified, filtered in $50 \mathrm{mM}$ ammonium bicarbonate buffer $\mathrm{pH} 8$ either on Sephadex G-25 fine $(1 \times 140 \mathrm{~cm} ; 10 \mathrm{ml} / \mathrm{h}$; volume of the fractions $0.8 \mathrm{ml})$ or on Bio-Gel P2 (100-200 mesh; $1 \times 110 \mathrm{~cm} ; 10 \mathrm{ml} / \mathrm{h}$; volume of the fractions $0.2 \mathrm{ml}$ ). In all cases, the peptides were purified by paper electrophoresis and/or paper chromatography as described above.

\section{Limited Tryptic Digestion of the SPE-Protein after Blocking the Lysine Residues}

The following procedure was used (see flow sheet in Fig. 1). The SPE-protein ( $36 \mathrm{mg}$ in $3.6 \mathrm{ml} 0.15 \mathrm{M}$ sodium tetraborate buffer $\mathrm{pH} 8.5$ ) was treated with three successive additions of $6.5 \mathrm{mg}$ of ETPA as described in [8]. The solution was dialysed at $4{ }^{\circ} \mathrm{C}$ against $50 \mathrm{mM} \mathrm{NH}_{4} \mathrm{HCO}_{3}$ buffer $\mathrm{pH} 8.0$ and after freeze-drying, the residue was submitted to tryptic digestion as described in [4]. Subsequently, the amino groups were generated by dissolving the digested material in $2 \mathrm{ml}$ $10 \%$ acetic acid and gently stirring the solution at room temperature for $16 \mathrm{~h}$. The solution was then filtered on Bio-Gel P6 in $50 \mathrm{mM}$ ammonium formate buffer $\mathrm{pH} 3.5$ and the peptides were purified by paper electrophoresis and paper chromatog. raphy as described above.

\section{Pepsin Cleavage of the Native Protein}

The native protein $(5.7 \mathrm{mg}$ in $0.3 \mathrm{ml} 10 \mathrm{mM}$ Tris $/ \mathrm{HCl}$ $\mathrm{pH} 8.3$ containing $2 \mathrm{mM} \mathrm{MgCl}_{2}$ ) was dialysed against $5 \%$ formic acid $(\mathrm{v} / \mathrm{v})$ and then supplemented with $1 \%(\mathrm{w} / \mathrm{w})$ pepsin). The solution $(0.5 \mathrm{ml})$ was incubated for $8 \mathrm{~h}$ at $37^{\circ} \mathrm{C}$ and then freeze-dried.

\section{Carboxypeptidase Y Cleavage of Peptides}

The selected peptide $(5-50 \mathrm{nmol})$, an equimolar amount of norleucine, and carboxypeptidase Y (protease/peptide: $1 / 30 ; \mathrm{w} / \mathrm{w}$ ) were incubated together at $37^{\circ} \mathrm{C}$ in $15-50 \mu \mathrm{l}$ of $50 \mathrm{mM}$ pyridine/acetic acid buffer $\mathrm{pH} 5.5$. Samples were removed after increasing times and the reaction was stopped by addition of $0.2 \mathrm{M}$ sodium citrate buffer $\mathrm{pH} 2.2$

\section{Peptide Nomenclature}

Capital letters refer to the methods used for the cleavage of the protein into peptide fragments. $\mathrm{CB}=$ cyanogen bromide; $\mathrm{T}=$ trypsin; $\mathrm{TL}=$ trypsin digestion limited at the Arg sites (after blocking the amino groups of lysine); TMI and TMS = trypsin digestion followed by radioactive labelling of the methionine residues and purification by either ion exchange (TMI) or molecular seiving (TMS); $\mathrm{C}=$ chymotryp$\sin ; \mathrm{TH}=$ thermolysin $\mathrm{SA}=S$. aureus protease; $\mathrm{AM}=A$. mellea protease; $\mathrm{P}=$ pepsin. Arabic numerals refer to the fractions (in the order of increasing elution volumes) collected by column chromatography and containing the relevant peptides. Small letters refer to further purification steps carried out on paper: letters in normal print $=$ paper electrophoresis at $\mathrm{pH} 6.5$; letters underlined $=$ paper electrophoresis at $\mathrm{pH} 3.5$; letters followed by an asterisk $=$ descend- 
ing paper chromatography. In each case, letters a, b, c, etc. indicate the relative position (from anode to cathode during electrophoresis or on the basis of increasing $R_{\mathrm{F}}$ values during chromatography) of the relevant peptide when compared to the other peptides present in the same preparation. Thus for example, peptide CB2T1eeb* was a peptide generated by cyanogen bromide cleavage of the SCM-protein and recovered in fraction 2 after column chromatography. Following further cleavage with trypsin, the peptide was recovered in fraction 1 after column chromatography. Finally, it was purified by paper electrophoresis at $\mathrm{pH} 6.5$, followed by paper electrophoresis at $\mathrm{pH} 3.5$, and paper chromatography. The peptide was in position e during the first and the second preparation methods, and in position b during the third one.

\section{Allocation of the Disulfide Bridges}

The diagonal technique of Brown and Hartley [27] was applied to the pepsin digest of the native protein. After the first electrophoresis at $\mathrm{pH} 6.5$ and subsequent treatment with performic acid, the second electrophoresis, carried out in a direction perpendicular to the first one, gave rise to three groups of peptides located outside the diagonal.

\section{Amide Assignment}

The amide groups were assigned both by identifying the phenylthiohydantoin and 4-N,N-dimethylaminoazobenzenethiohydantoin derivatives and on the basis of the electrophoretic mobilities of the peptides at $\mathrm{pH} 6.5$ [28].

\section{Search for Sequence Homology and Repetitive Fragments}

The search for homology between different sequences or repetitive fragments in the same sequence was carried out by comparing all possible spans of $n$ (3 to 25) contiguous amino acids [29]. The amino acids were compared on the basis of a structural test which made use of the relative frequencies of substitution found in different families of homologous proteins [30].

\section{RESULTS}

The amino acid sequence of the DD-peptidase is shown in Fig. 2. It was established as described in the ensuing and miniprint sections.

\section{Intact Protein and Cyanogen Bromide Fragments}

Table 2 presents the amino acid composition of the protein as found after acid hydrolysis and as deduced from the primary structure. The value of 22076 thus obtained for the $M_{\mathrm{r}}$ was $20 \%$ larger than that determined by polyacrylamide gel electrophoresis in the presence of SDS. Asp (or Asn) was at the $\mathrm{N}$ terminus and Ile at the $\mathrm{C}$ terminus of the protein, as shown by dansylation and hydrazinolysis experiments, respectively. $\mathrm{Nbs}_{2}$ (Ellman's reagent) failed to detect any free $\mathrm{SH}$ group (even after denaturation of the protein). Neither S-glyceryl-cysteine thioether (as found in the Braun's lipoprotein of Escherichia coli [21]), nor sugar residues were detected. Fragmentation of the SCM-protein with cyanogen bromide yielded five fragments designated, in the order of decreasing sizes, CB2, CB3, CB4, CB5 and CB6 (see Materials and Methods, and Table 3).
Table 2. Amino acid composition of the performic-acid-oxidized protein The first three columns give the amounts of amino acid residues as obtained after increasing periods of hydrolysis with $6 \mathrm{M} \mathrm{HCl}$ at $110 \mathrm{C}$. Trp was determined on a separate sample of the native protein after hydrolysis for $96 \mathrm{~h}$ at $110^{\circ} \mathrm{C}$ with $3 \mathrm{M}$ mercaptoethane sulfonic acid

\begin{tabular}{|c|c|c|c|c|c|c|}
\hline \multirow[t]{2}{*}{$\begin{array}{l}\text { Amino } \\
\text { acid }\end{array}$} & \multicolumn{4}{|c|}{ Amount after } & \multicolumn{2}{|c|}{$\begin{array}{l}\text { Number of residues } \\
\text { as calculated from }\end{array}$} \\
\hline & $24 \mathrm{~h}$ & $48 \mathrm{~h}$ & $72 \mathrm{~h}$ & mean & hydrolysis & sequence \\
\hline & \multicolumn{4}{|c|}{$\mathrm{nmol} / \mathrm{mg}$} & & \\
\hline Lys & 0.233 & 0.242 & 0.256 & 0.244 & 5.07 & 5 \\
\hline His & 0.328 & 0.362 & 0.341 & 0.344 & 7.14 & 7 \\
\hline Arg & 0.459 & 0.462 & 0.471 & 0.464 & 9.64 & 10 \\
\hline Cya & 0.261 & 0.265 & 0.233 & 0.253 & 5.25 & 6 \\
\hline Asp & 1.074 & 1.100 & 1.063 & 1.079 & 22.41 & 22 \\
\hline Thr & 0.618 & 0.619 & 0.619 & 0.619 & 12.85 & 13 \\
\hline Ser & 0.682 & 0.683 & 0.677 & 0.681 & 14.14 & 15 \\
\hline Glu & 0.728 & 0.743 & 0.713 & 0.728 & 15.12 & 15 \\
\hline Pro & 0.360 & 0.392 & 0.417 & 0.389 & 8.08 & 8 \\
\hline Gly & 1.487 & 1.485 & 1.520 & 1.497 & 31.09 & 31 \\
\hline Ala & 1.427 & 1.462 & 1.417 & 1.435 & 29.80 & 29 \\
\hline Val & 0.459 & 0.466 & 0.462 & 0.462 & 9.59 & 10 \\
\hline $\mathrm{MetO}_{2}$ & 0.166 & 0.175 & 0.152 & 0.164 & 3.41 & 4 \\
\hline Ile & 0.336 & 0.336 & 0.336 & 0.336 & 6.99 & 7 \\
\hline Leu & 0.519 & 0.530 & 0.543 & 0.531 & 11.03 & 11 \\
\hline Tyr & 0.237 & 0.239 & 0.278 & 0.251 & 5.21 & 7 \\
\hline Phe & 0.385 & 0.392 & 0.408 & 0.395 & 8.20 & 8 \\
\hline Trp & 4.82 & & & & 4.82 & 4 \\
\hline
\end{tabular}

Table 3. Amino acid composition of the peptides produced by $\mathrm{CNBr}$ fragmentation of the SCM-protein

Number of residues as obtained after acid hydrolysis with $6 \mathrm{M} \mathrm{HCl}$ for $24 \mathrm{~h}$ at $110^{\circ} \mathrm{C}$. The figures in parentheses give the relevant numbers as obtained by sequencing

\begin{tabular}{|c|c|c|c|c|c|}
\hline \multirow[t]{2}{*}{ Residue } & \multicolumn{5}{|c|}{ Amount in fragment } \\
\hline & $\mathrm{CB} 2$ & CB3 & CB4 & CB5 & CB6 \\
\hline Lys & $3.25 \quad(3)$ & & $0.94(1)$ & $0.87(1)$ & \\
\hline His & & $4.49 \quad(5)$ & $0.68(1)$ & & $1.10(1)$ \\
\hline Arg & $5.31 \quad(5)$ & $1.95 \quad(2)$ & $1.69(2)$ & & 0.91 (1) \\
\hline CmCys & $2.29 \quad(3)$ & 2.31 & $0.19(1)$ & & \\
\hline Asp & $12.98(12)$ & $5.90 \quad(5)$ & $5.10(5)$ & & \\
\hline Thr & 8.41 (9) & $2.11 \quad(2)$ & $1.74(2)$ & & \\
\hline Ser & $6.86 \quad(8)$ & $2.93 \quad(3)$ & $3.60(4)$ & & \\
\hline Glu & $10.92(11)$ & $2.69 \quad(3)$ & & $0.97(1)$ & \\
\hline Pro & $3.98 \quad(4)$ & $3.20 \quad(3)$ & $0.93(1)$ & & \\
\hline Gly & $14.16(14)$ & $10.98(12)$ & $4.90(5)$ & & \\
\hline Ala & $16.53(17)$ & 7.56 & $1.23(1)$ & 0.99 & $1.32(1)$ \\
\hline Val & $5.31 \quad(6)$ & 1.30 & $2.83(3)$ & & \\
\hline Ile & $3.39 \quad(4)$ & $1.68 \quad(2)$ & 0.84 (1) & & \\
\hline Leu & $6.42 \quad(7)$ & $2.93 \quad(3)$ & & $1.17(1)$ & \\
\hline Tyr & $4.28 \quad(5)$ & $1.71 \quad(2)$ & & & \\
\hline Phe & $3.91 \quad(4)$ & $3.05 \quad(3)$ & $0.90(1)$ & & \\
\hline Trp & $? \quad(2)$ & $? \quad(1)$ & $?$ & $? \quad(1)$ & \\
\hline Hse & $0.99 \quad(1)$ & & $0.54(1)$ & $0.56(1)$ & $0.95(1)$ \\
\hline Total & 115 & 58 & 29 & 6 & 4 \\
\hline
\end{tabular}

\section{The CB2 Peptide Fragment (115 Residues)}

Automatic sequencing revealed that the first six residues were Asn-Gly-Xaa-Tyr-Thr-Trp. The yield of phenylthiohydantoins was very low $(2.5 \%)$ although, as controlled with whale sperm myoglobin, the sequenator was in perfect ope- 
ASN-GLY-CYS-TYR-THR-TRP-SER -GLY-THR-LEU-SER-GLU-GLY-SER-SER-GLY-GLU-ALA-VAL-ARG -GLN-LEU-GLN-ILE-ARGL. 80
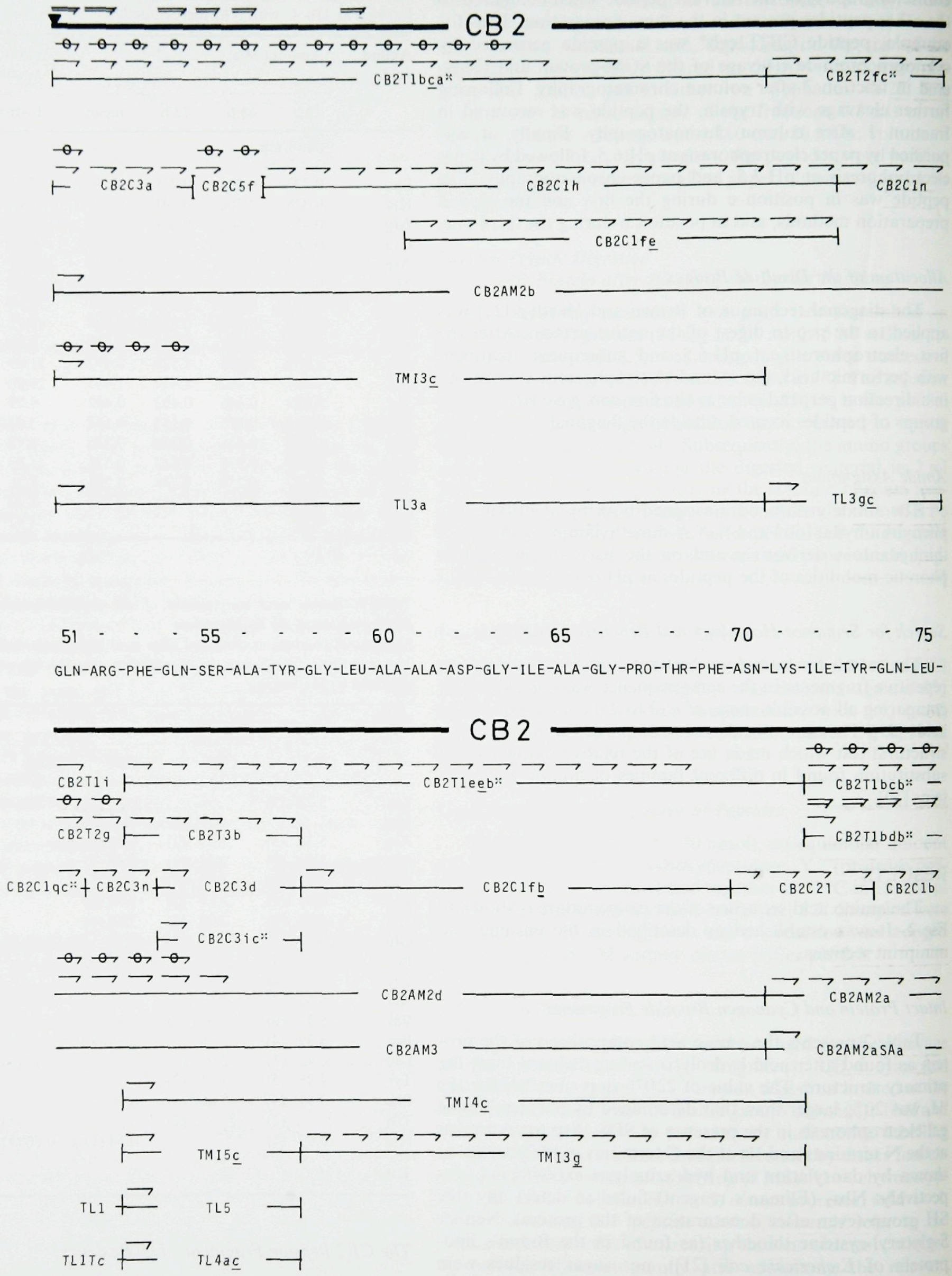

Fig. 2. Amino acid sequence of the $G \mathrm{Zn}^{2+}$ DD-carboxypeptidase. The CNBr peptide fragments of the SCM-protein are represented by heavy lines between hydrolysis and sequencing gave rise to identical or at least consistent data. The methods used for sequencing are represented by the following symbols: : carboxypeptidase Y 
LYS-VAL-SER-ALA-ALA-THR-ALA-ARG -ALA-ASN-ALA-LEU-VAL-THR-MET-TRP-LYS-LEU -GLN-ALA-MET-ARG-HIS-ALA-MET-
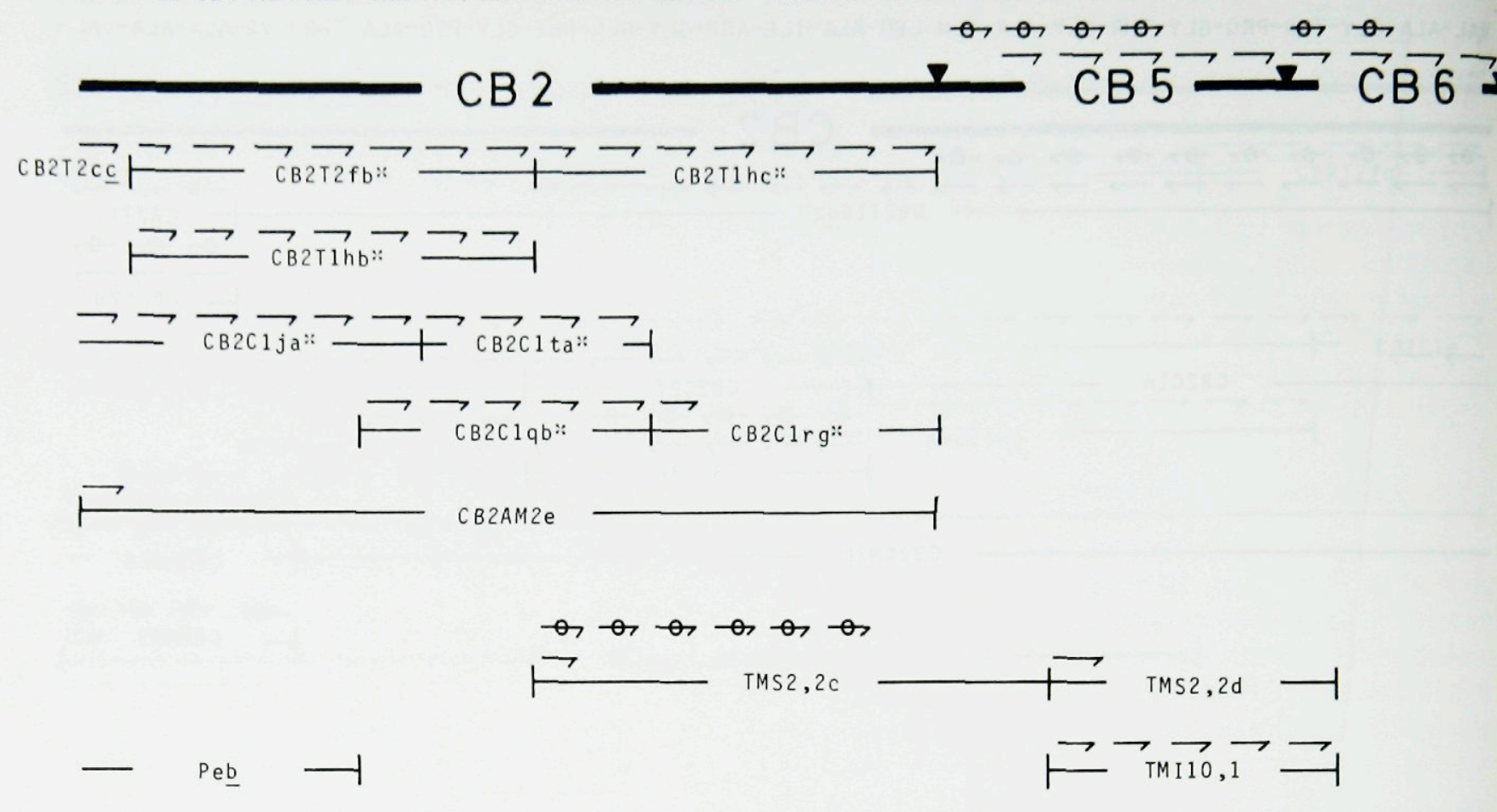

Fig. $2 \mathrm{e}-\mathrm{h}$ 
GLY-ASP-LYS-PRO-ILE-THR-VAL-ASN-GLY-GLY-PHE-ARG - SER-VAL-THR-CYS-ASN-SER-ASN-VAL-GLY-GLY-ALA-SER-ASN93.

\section{$\theta \rightarrow \theta, \theta, \theta, \theta$}

$\longrightarrow \longrightarrow \longrightarrow \overrightarrow{\mathrm{CB} 4 \mathrm{Cb}}$

$\longrightarrow \rightarrow \longrightarrow \rightarrow \longrightarrow \rightarrow C B A C d$

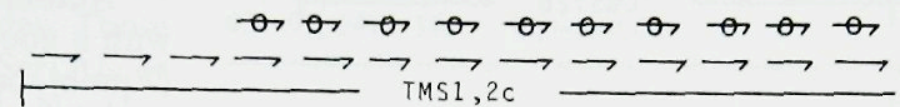

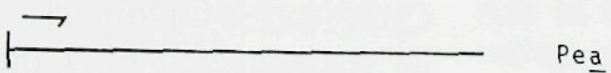

Pea

$\longrightarrow \rightarrow \longrightarrow$

TL2fb:

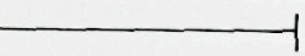

$176--\quad 180-\quad-\quad 185-200$ ARG -ASN-HIS-GLY-PHE-THR-GLU-ILE-LEU-GLY-PRO-GLY-TYR-PRO-GLY-HIS-ASN-ASP-HIS-THR-HIS-VAL-ALA -GLY-GLY $\Longrightarrow$

CB 3

CB3 T1

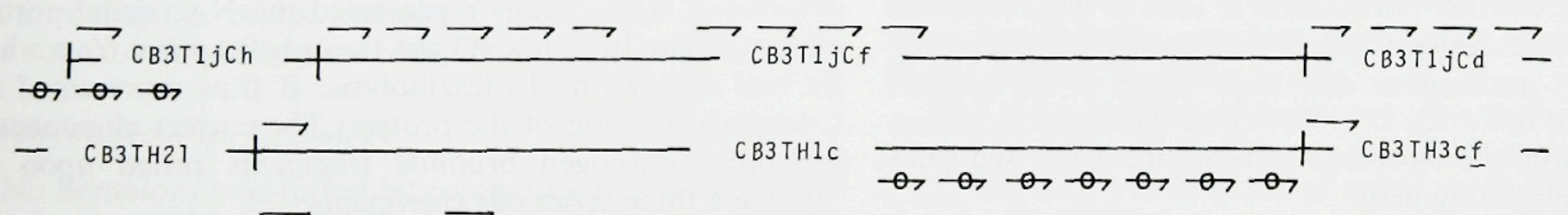

$\Longrightarrow \Longrightarrow \Longrightarrow \Longrightarrow \Longrightarrow \Longrightarrow \Rightarrow \Rightarrow$

$\longrightarrow$

CB3T1

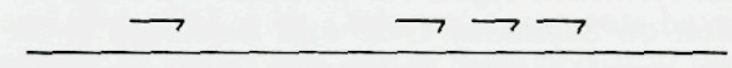

С В3тн5b

CB3TH1 e

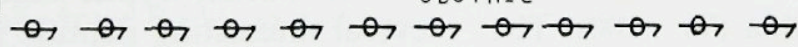

CB3SAla $\longrightarrow \rightarrow \longrightarrow \rightarrow \rightarrow \longrightarrow \rightarrow \longrightarrow \rightarrow$

CB3SA2ea*

TMI8 $\underline{b}$

$\longrightarrow \quad T L 2 g$

$\longrightarrow \rightarrow \longrightarrow \rightarrow \rightarrow \longrightarrow \rightarrow \longrightarrow \rightarrow \mathrm{TL} 2 \mathrm{~h}$ 


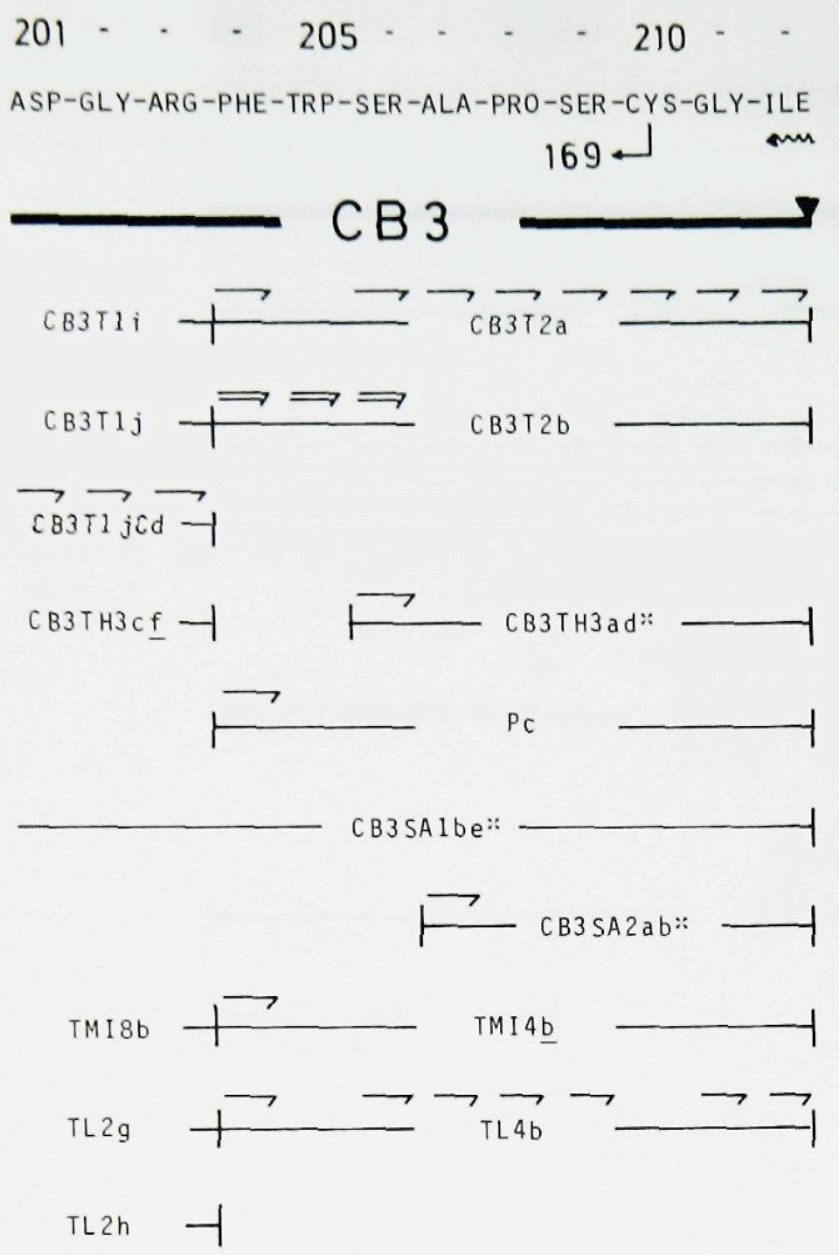

Fig. $2 \mathrm{i}$

ration conditions. This suggested a partial cyclization of the dipeptide Asn-Gly in the form of the anhydro-aspartylglycine imide [31].

CB2 was exhaustively digested by trypsin, chymotrypsin and Armillaria mellea protease, using 2, 2 and $1.2 \mu \mathrm{mol}$ of $\mathrm{CB} 2$, respectively. The tryptic and chymotryptic digests on the one hand and the $A$. mellea digest on the other were fractionated by filtration on Sephadex G-25 and Sephadex G-50, respectively. The tryptic digest resulted in three fractions (CB2T 1-3), the chymotryptic digest in five fractions (CB2C1-5), and the A. mellea digest in three fractions (CB2AM1 - 3). Further purification of each of these fractions by paper electrophoresis and paper chromatography permitted isolation, final purification and sequencing of the peptide fragments listed in Tables $1-3 \mathrm{M}$. On the basis of their amino acid composition, these peptides covered the whole sequence of the CB2 peptide fragment.

Two overlaps at positions $85-86$ and $90-91$ were elucidated thanks to the peptide CB2AM2a $(71-100)$. The Staphylococcus aureus protease cleaved this peptide $(75 \mathrm{nmol})$ into two fragments (Table 4M). The N-terminal fragment was digested with carboxypeptidase $\mathrm{Y}$ (Table $5 \mathrm{M}$ ) permitting the ordering of the chymotryptic peptides $\mathrm{CB} 2 \mathrm{C} 2 \mathrm{c}(88-90)$ and $\mathrm{CB} 2 \mathrm{C} 4 \mathrm{e}(86-87)$. In turn, the $\mathrm{C}$-terminal portion was sequenced, yielding a good overlap between the chymotryptic peptides $\mathrm{CB} 2 \mathrm{C} 2 \mathrm{C}(88-90)$ and $\mathrm{CB} 2 \mathrm{C} 3 \mathrm{fa}(91-97)$. At this stage, two peptide regions were weakly established. One involved the residues $69-71$ and the other the residues $37-53$. This latter region included the overlap between $\mathrm{CB} 2 \mathrm{C} 2 \mathrm{f}$ $(37-42)$ and $\mathrm{CB} 2 \mathrm{C} 1 \mathrm{qc} *(43-51)$. These ambiguities were elucidated by sequencing TMI3g $(58-71)$ and TL1 $(26-52)$, respectively.
Surprisingly, the $\mathrm{Tyr}^{57}$-Gly ${ }^{58}$ bond was cleaved during trypsin treatment with a yield of $7.4 \%$, indicating some chymotryptic activity of the trypsin (despite treatment to remove it). Note that the same bond was also cleaved during tryptic digestion of the SCM-protein (yield $11.4 \%$ ) and during limited tryptic digestion of the SEP-protein (yield up to $24 \%$ )

\section{The CB3 Peptide Fragment (58 Residues)}

Automatic sequencing of CB3 gave the first 22 residues with a good yield. CB3 was exhaustively digested by trypsin ( $2 \mu \mathrm{mol}$ peptide), thermolysin $(1 \mu \mathrm{mol})$ and the $S$.aureus protease $(1 \mu \mathrm{mol})$, respectively, and the peptides listed in Tables $6-8 \mathrm{M}$ were isolated and sequenced. Peptide CB3T1j $(177-203)$ was digested by chymotrypsin (Table 9M) permitting elucidation of the complete sequence of CB2.

The following aspecific cleavage sites in CB3 were observed. Trypsin cleaved the $\mathrm{His}^{157}-\mathrm{Ala}^{158}$ bond with a yield of $2.4 \%$ [generating peptide CB3T2e $(155-157)$ ] and the bond Ala ${ }^{170}-$ Leu $^{171}$ with a yield of $6.2 \%$ [generating peptide CB3T1d $(155-170)]$. The $S$. aureus protease used seemed to be contaminated by a thermolysin-like protease and gave rise to several parasite peptides (Table $8 \mathrm{M}$ ). Finally, dansylation of peptide CB3SA1be*, followed by $6 \mathrm{M} \mathrm{HCl}$ hydrolysis for $8 \mathrm{~h}$, yielded both Dns-Ile and a parasite compound probably Dns-Ile-Leu, migrating close to Dns-Phe. Dns-Ile alone was obtained after prolonged (72-h) hydrolysis.

\section{The CB4 Peptide Fragment (29 Residues)}

Manual sequencing of CB4 gave the first 14 residues. The complete sequence was elucidated after subdigestion of CB4 with chymotrypsin (Table $10 \mathrm{M}$ ) and by purifying TMS1,2c $(138-152)$, a tryptic peptide of the SCM-protein (see further).

\section{The CB5 and CB6 Fragments (6 and 4 Residues, Respectively)} ally.

Sequencing of both these peptides was carried out manu-

\section{Assembly of the CB2, CB3, CB4, CB5} and CB6 Peptide Fragments

$\mathrm{CB} 2$ was the only $\mathrm{CNBr}$ fragment which possessed an $\mathrm{N}$-terminal Asn. It thus represented the $\mathrm{N}$-terminal portion of the protein. In turn, CB3 was the only fragment from which Ile was released hy hydrazinolysis. It thus represented the C-terminal portion of the protein. The correct alignment of the other cyanogen bromide fragments rested upon the following three series of experiments.

The limited tryptic digestion of the SEP-protein yielded several interesting peptide fragments (Table $11 \mathrm{M}$ ). In particular, peptide TL2fb* $(123-137)$ provided the necessary overlap between CB6 and CB4 and peptide TL3gd (153-157) which resulted from a side cleavage of trypsin after His ${ }^{157}$, provided the necessary overlap between CB4 and CB3. The presence of the bond $\mathrm{Lys}^{47}-\mathrm{Ala}^{48}$ (which is normally sensitive to trypsin) in peptide TL1 $(26-52)$ demonstrated the efficiency of the procedures used initially to block the amino groups of the lysine residues. Peptide TL1 was subsequently digested by trypsin and the two expected fragments were isolated (Table $12 \mathrm{M}$ ).

The exhaustive tryptic digestion of the SCM-protein followed by radioactive labelling of the methionine residues yielded, after ion-exchange chromatography (procedure A), 
three radioactive fractions (TMI9, TMI10 and TMI12) (Fig. 3M,a) and nine non-radioactive fractions (TMI1TMI8 and TMI11) (Fig. 3 M,b and Table $13 \mathrm{M}$ ). After regeneration of the methionine residues and an additional ionexchange chromatography, peptide TMI10 yielded peptide TMI10,1 (118-122) (Fig. $4 \mathrm{M}$ and Table $13 \mathrm{M}$ ) which provided the necessary overlap between CB5 and CB6.

Finally, fractionation of the same radioactively labelled digest as above on Bio-Gel P6 (procedure B) followed by regeneration of the methionine residues and filtration on suitable Sephadex columns yielded several peptides. Those possessing a His (on the basis of Pauly's test) or a Ser, Ala or Leu at the $\mathrm{N}$ terminus were further investigated. No Hiscontaining peptide could be purified but three peptides TMS1,2c (138-152), TMS2,2c (109-117) and TMS2,2d $(118-122)$ were obtained in pure form (Table 14M). Peptide TMS2,2d (118-122) contained one methionine residue. Peptide TMS1,2c (138-152) was a tryptic peptide of CB4 and was helpful in completing the sequence of CB4. Peptide TMS2,2c provided the necessary overlap between CB2 and CB5.

\section{Allocation of the Disulfide Bridges}

The technique of diagonal paper electrophoresis at pH 6.5 allowed several peptides to be detected (Fig. 5M). After performic oxidation, two acidic peptides became more acidic (peptides $\mathrm{Pa}$ and $\mathrm{Pb}$ ), two neutral peptides became acidic (peptides $\mathrm{Pc}$ and $\mathrm{Pd}$ ) and two basic peptides became neutral. These latter peptides, Pea and Peb, were further separated by paper electrophoresis at $\mathrm{pH} 3 . \overline{5}$. The analyses of all the peptides are shown in Table $15 \mathrm{M}$. The couple Pea and Peb represented the sequences $134-150$ and $91-106$, respectively, thus demonstrating the occurrence of a $\mathrm{S}^{93}-\mathrm{S}^{141}$ disulfide bridge. The couple $\mathrm{Pd}-\mathrm{Pc}$ represented the sequences $168-174$ and $204-211$, respectively, thus demonstrating the occurrence of a $\mathrm{S}^{169}-\mathrm{S}^{210}$ disulfide bridge. The peptides $\mathrm{Pa}$ and $\mathrm{Pb}$, however, differed from each other only by the presence of an additional residue in $\mathrm{Pb}$; they represented the sequences $78-84$ and $78-85$, respectively. The procedure thus provided only one of the two peptide partner possibly involved in a third disulfide bridge. However, the fact that the protein (either native or denatured by guanidinium chloride or SDS) had no detectable SH group, carbohydrate moiety nor $S$-glycerol-cysteine thioether left little doubt on the occurrence of a third disulfide bridge extending between $\mathrm{Cys}^{3}$ and $\mathrm{Cys}^{80}$. This conclusion was confirmed by crystallographic data [3].

\section{Search for Sequence Homology}

No homology was found by comparing the DD-peptidase with (a) the $\mathrm{Zn}^{2+}$-containing enzymes carboxypeptidase $\mathrm{A}$ [31], thermolysin [32], carbonic anhydrase B [33] and alcohol dehydrogenase [34]; (b) the partially sequenced serine DD-carboxypeptidase of Bacillus subtilis and Bacillus stearothermophilus [35]; (c) the $\mathrm{Zn}^{2+} \beta$-lactamase II of Bacillus cereus (Ambler; personal communication); and (d) other serine $\beta$-lactamases $[36,37]$. Using the same computer program, internal homology in the DD-peptidase was found only in a few peptide regions containing at the most 10 amino acid residues (Table 4).

\section{DISCUSSION}

There is an excellent agreement between the amino acid composition of the DD-peptidase shown in Table 2 and the
Table 4. Internal sequence identities in the DD-peptidase

\begin{tabular}{ll}
\hline Peptide region & Sequence \\
\hline $57-66,155-164$ & Tyr-Gly- Leu-Ala-Ala-Asp- Gly Lle ${ }_{\text {Leu Gly }}$-Ala-Gly \\
$28-31,187-190$ & $\begin{array}{l}\text { Gly-Tyr-Pro-Gly } \\
\text { Trp-Ser-Gly }\end{array}$ \\
$5-8,96-98$ & Arg-Phe-Gln-Ser-Ala \\
$52-56,203-207$ & Trp \\
$93-95,141-143$ & Cys-Asn-Ser \\
\hline
\end{tabular}

amino acid sequence proposed in Fig. 2. However, a few peptide bonds were only proved weakly. The $\mathrm{Arg}^{203}-\mathrm{Phe}^{204}$ bond was established on the basis of peptide CB3SA1be* $(182-212)$ only and the $\mathrm{Met}^{154}-\mathrm{Tyr}^{155}$ bond on the basis of peptide TL3gd $(153-157)$ resulting from a tryptic side reaction of poor yield $(3.5 \%)$. Deamidation and cyclization of Asn in the Asn ${ }^{1}-G_{1}{ }^{2}$ sequence probably explains the difficulties encountered in attempts to sequence both the SCMprotein (C. Duez, personal communication) and the $\mathrm{CNBr}$ peptide fragment CB2. Reopening of the cyclic imide with generation of a mixture of $\alpha$ and $\beta$-aspartyl peptides [38] probably explains why Asp, instead of Asn, has been located at the $\mathrm{N}$ terminus of the peptides $\mathrm{CB} 2 \mathrm{C} 3 \mathrm{a}, \mathrm{CB} 2 \mathrm{~T} 1 \mathrm{bca}$ * and TMI 3c. Usually, $\alpha$ and $\beta$-aspartyl peptides can be separated by electrophoresis at $\mathrm{pH} 3.5$ [39] and peptide CB2C 3a was indeed found to be heterogenous under these conditions.

Among the 212 residues which constitute the DD-peptidase, 14 are acidic (4 Glu and $10 \mathrm{Asp}$ ) and 15 are basic (5 Lys and $10 \mathrm{Arg}$ ), providing a ratio of uncharged residues to charged residues of 7.31. The protein possesses 11 segments, each containing from 8 up to 15 uncharged residues in sequence. These segments which altogether comprise 113 residues, are as follows (the hydrophobicity index calculated according to Segrest [40] is given into parenthesis): $1-11(1.2), 26-38$ (1.5), $53-61$ (1.6), $63-70$ (1.4), $80-88$ (1.6), 109-116 (2.1), $129-136(1.7), 138-151(0.1), 161-175(1.0), 183-192(1.6)$ and $204-212(2.0)$. Only two fragments have a high hydrophobic character and one of them occurs at the $\mathrm{C}$ terminus of the protein. The His and Met residues fall exclusively in the $\mathrm{C}$-terminal half of the sequence. The cyanogen peptide fragment CB3 $(155-212)$ contains five His residues out of the seven found in the complete polypeptide chain. Out of the 15 Glx present, 11 occur as Gln.

The DD-peptidase shows very few internal repetitive sequences and no homology is found by comparing the sequence of Fig. 2 with those of other mechanistically and/or functionally related enzymes. In agreement with this latter conclusion, the interpretation of the $2.5-\AA(0.25-\mathrm{nm})$ electron density map of the DD-peptidase has revealed a secondary and tertiary structure not found in any other protein [3]. Considering that a full characterization must await final fitting of the protein molecule in the Richard's box and crystallographic refinements, the structure proposed on the basis of these X-ray studies [3] is in very good agreement with the amino acid sequence shown in Fig. 2. The protein consists of an $\mathrm{N}$-terminal domain $(1-76)$ and a C-terminal domain $(81-212)$ which are connected via a single peptide sequence $\mathrm{Leu}^{75}$-Gln-Asp-Asp-Asp-Cys ${ }^{80}$ (itself involved in a disulfide bridge with $\mathrm{Cys}^{3}$ ). The catalytic cavity is located in the large domain. Using the present numbering, important residues are His $^{153}$, His ${ }^{194}$ and His ${ }^{196}\left(\mathrm{Zn}^{2+}\right.$ ligands) and, probably, 
$\mathrm{His}^{191}$ (proton donor?) and $\mathrm{Arg}^{137}$ (charge pairing with the carboxylate substrate?).

The work in Liège was supported in part by the Fonds de la Recherche Scientifique Médicale, Brussels (grant 3.4501.79), the Belgian Government (Action concertee 79 84-I1) and the U.S. National Institutes of Health, Bethesda (grant 2 R01 13364-05). J. V. B. is indebted to the National Fonds voor Webenschappelijk Onderzoek. Brussels (kredit aan Navorsers 52 -AM.E98). The skilful assistance of $\mathrm{Mr} \mathrm{D}$. Klein (Liège; purification of the DD-peptidase), Mr J. Van Damme (Gent; phenylthiohydantoin analyses) and Mr S. Collin (Liège; amino acid analyses) is greatly appreciated. We thank Professor G. Hamoir (Laboratoire de Biochimie musculaire, Liège) and Professor J. De Ley (Laboratorium voor Microbiologie, Gent) for their hospitality and interest. This paper is from a dissertation to be submitted by B. J. in partial fulfilment of the requirements for a degree of Dr en sciences chimiques at the University of Liège, Belgium

\section{REFERENCES}

1. Ghuysen, J. M., Frère, J. M., Leyh-Bouille, M., Dideberg, O., Lamotte-Brasseur, J., Perkins, H. R. \& De Coen, J. L. (1981) in Topics in Molecular Pharmacology (Burgen, A. S. V. \& Roberts, G. C. K., eds) pp. 64-97, Elsevier/North-Holland, Amsterdam.

2. Dideberg, O., Joris, B., Frère, J. M., Ghuysen, J. M., Weber, G., Robaye, R., Delbrouck, J. M. \& Roelandts, I. (1980) FEBS Lett. $117,215-218$

3. Dideberg, O., Charlier, P., Dive, G., Joris, B., Frère, J. M. \& Ghuysen, J. M. (1982) Nature (Lond.) 299, 469-470.

4. Duez, C., Frère, J. M., Geurts, F., Ghuysen, J. M., Dierickx, L. \& Delcambe, L. (1978) Biochem. J. 175, $793-800$.

5. Bibring, T. \& Baxandall, J. (1978) Anal. Biochem. 85, 1-14.

6. Friedman, M., Krull, L. H. \& Cavins, J. F. (1970) J. Biol. Chem. 245, $3868-3871$

7. Hirs, C. H. W. (1967) Methods Enzymol. 11, 197-199

8. Riley, M. \& Perham, R. N. (1970) Biochem. J. 118, 733-739.

9. Penke, B., Ferenczi, R. \& Kovacs, K. (1974) Anal. Biochem. 60, $45-50$.

10. Gray, R. W. (1972) Methods Enzymol. 25, 121-143.

11. Hartley, B. S. (1970) Biochem. J. 119, 805-822.

12. Edman, P. \& Begg, G. (1967) Eur. J. Biochem. 1, 80-91.
13. Hunkapillar, M. \& Hood, L. (1978) Biochemistry, 17, 2124-2133.

14. Wittmann-Liebold, B., Geissler, A. W. \& Marzimig, E. (1975) J. Supramol. Struct. 3, 426-447.

15. Van Beeumen, J., Van Damme, J., Tempst, P. \& De Ley, J. (1980) in Methods in Peptide and Protein Sequence Analysis (Birr, C., ed.) pp. 503-506, Elsevier/North-Holland, Amsterdam.

16. Zimmermann, C. L., Appella, E. \& Pisano, J. J. (1977) Anal. Biochem. 77, 569-573.

17. Dognin, M. J. \& Wittmann-Liebold, B. (1980) Eur. J. Biochem. 112, $131-151$

18. Wittmann-Liebold, B. \& Lehmann, A. (1980) in Methods in Peptide and Protein Sequence Analysis (Birr, C., ed.) pp. 49-72, Elsevier/ North-Holland, Amsterdam.

19. Habeeb, A. F. S. A. (1972) Methods Enzymol. 25, 457-464.

20. Dubois, A. S. (1956) Anal. Chem. 28, 350.

21. Hantke, K. \& Braun, V. (1973) Eur. J. Biochem. 34, 284-296.

22. Vandekerckhove, J. \& Van Montagu, M. (1974) Eur. J. Biochem. 44, $279-288$.

23. Toennies, G. \& Kolb, J. J. (1951) Anal. Chem. 23, 823-826.

24. Mann, T. \& Leone, E. (1953) Biochem. J. 53, 140-148.

25. Degen, J. \& Kyte, J. (1978) Anal. Biochem. 89, 529-539.

26. Lai, Y. (1977) Methods Enzymol. 47, 236-243.

27. Brown, J. R. \& Hartley, B. S. (1966) Biochem. J. 101, 214-228.

28. Offord, R. E. (1977) Methods Enzymol. 47, 51-67.

29. Fitch, W. M. (1966) J. Mol. Biol. 16, 9-16.

30. McLachlan, A. D. (1971) J. Mol. Biol. 61, 409-424.

31. Titani, K., Ericsson, L. H., Walsh, K. A. \& Neurath, H. (1975) Proc. Natl Acad. Sci. USA, 72, 1666-1670.

32. Titani, K., Hermodson, M. A., Ericsson, L. H., Walsh, K. A. \& Neurath, H. (1972) Nature (Lond.) 238, 35-37.

33. Andersson, B., Nyman, P. O. \& Strid, L. (1972) Biochim. Biophys. Acta, 48, 670-677.

34. Jörnvall, H. (1970) Eur. J. Biochem. 16, 25-40.

35. Waxman, D. J., Yocum, R. R. \& Strominger, J. L. (1980) Phil. Trans. R. Soc. Lond. B289, 257-275.

36. Ambler, R. P. (1980) Phil. Trans. R. Soc. Lond. B289, 321-331.

37. Jaurin, B. \& Grundström, M. T. (1981) Proc. Natl Acad. Sci. USA, $78,4897-4901$

38. Borstein, P. \& Balian, G. (1977) Methods Enzymol. 47, 132-145

39. Ambler, R. P. (1975) Biochem. J. 151, 197-218.

40. Segrest, J. P. \& Feldmann, R. J. (1974) J. Mol. Biol. 87, 853-858.

B. Joris, J. M. Frére, and J. M. Ghuysen, Laboratoire de Microbiologie, Faculté de Médecine de l'Université de Liège,

Institut de Chimie Organique et de Biochimie, Université de Liège au Sart-Tilman,

4000 Liège, Belgium

F. Casagrande and C. Gerday,

Laboratoire de Biochimie Musculaire, Institut de Chimie Organique et de Biochimie, Université de Liège au Sart-Tilman,

B-4000 Liège, Belgium

J. Van Beeumen, Laboratorium voor Microbiologie en Microbiële Genetica, Faculteit der Wetenschappen, Rijksuniversiteit Gent,

K. L. Ledeganckstraat, 35, B-9000 Gent, Belgium 
Miniprint section to

The complete amino acid sequence of the $2 n^{++}$-containing 0 -alanyl-0 alanine-cleaving carboxypeptidase of streptomyces a brua 6 by

B. Joris, J. Van Beeumen, F, Casagrande, Ch. Gerday, J.M. Frère and

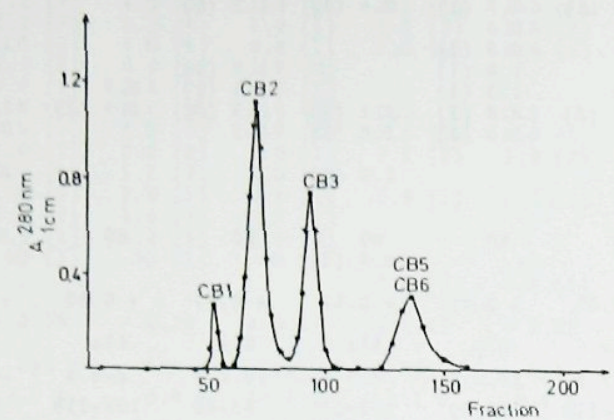

Sapation of the peptide fragments produced by CNBr cleavage The peptides soluble in $0.2 \mathrm{M} \mathrm{NH}_{4} \mathrm{HCO}_{3}$ buffer $\mathrm{pH} 8.6$ were filtered on a $2.5 \times 150 \mathrm{~cm}$ column of Sephadex $\mathrm{G}=50$ fine in the same bicarbonate buffer. Flow rate : $35 \mathrm{ml} / \mathrm{h}$. Volume of the
fractions : $5.3 \mathrm{ml}$.

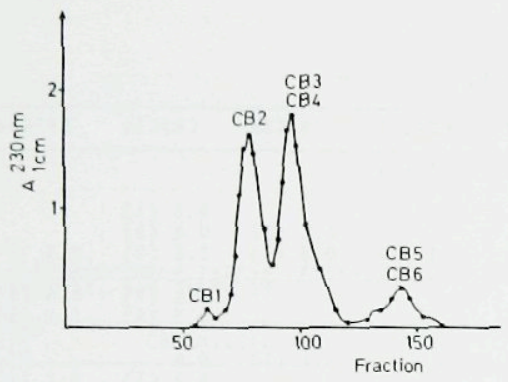

Fig. 24. Separation of the peptide fragments produced by CNBr cleavage of the SCM-protein 0.8 Hmoll

Ail the peptides were solubilized in $50 \mathrm{mM}$ ammonium formate buffer pH 3.5 supplemented with 2 M guanidinium chloride and the resulting solution was filtered on a $1.25 \times 150 \mathrm{~cm}$ column of Sephadex G-50 fine in the same ammonium formate buffer wi thout guanidinium chloride). Flow rate $15 \mathrm{ml} / \mathrm{h}$. Volume (withe fractions
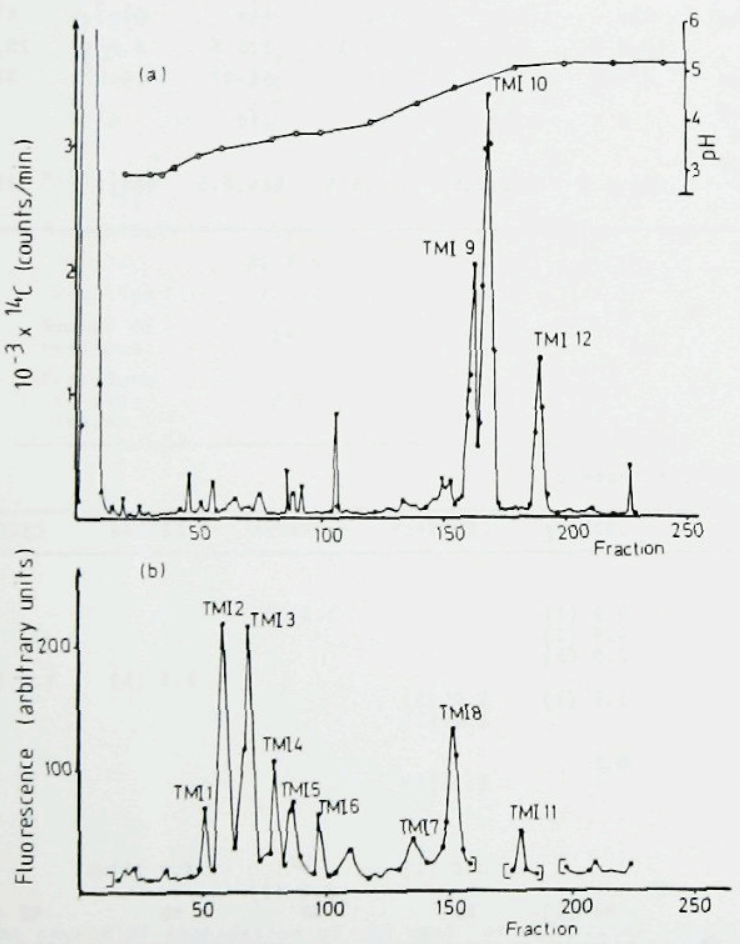

Pig. 3M. Fractionation of the tryptic digest of the SCM-protein by

After tryptic digestion, the methionine residues were labelled with iodo $\left[{ }^{14} \mathrm{C}\right]$ ace tamide. The sample, dissolved in $30 \mathrm{~h}$ acetic acid, was applied to a $0.8 \times 24.5 \mathrm{~cm}$ column preequilibrated against buffer $A$ successively with $: 75 \mathrm{ml}$ of buffer $A: 300 \mathrm{ml}$ was carrear gradient obtained with $150 \mathrm{ml}$ of buffer $A$ and $150 \mathrm{ml}$ of buffer $B(50 \mathrm{mM}$ pyridinium acetate $\mathrm{pH} 3.75) ; 300 \mathrm{ml}$ of a linear gradient obtained with $150 \mathrm{ml}$ of buffer $B$ and $150 \mathrm{ml}$ of buffer C (2 M pyridinium acetate PH 5.0): and, finally, buffer $C$ alone. The fractions were analysed by liquid b). Flow rate: $16.3 \mathrm{ml} / \mathrm{h}$; volume of the fractions: $3.4 \mathrm{ml}$

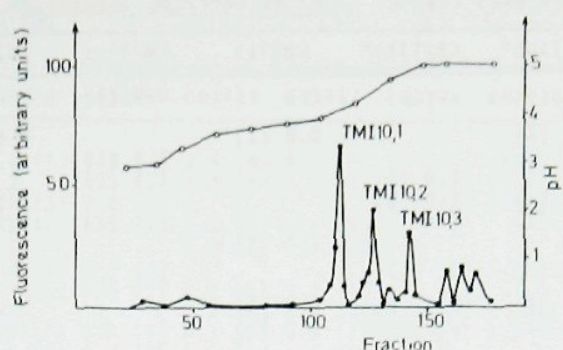

Fig. 4M. Fractionation of peptidec TMI10 (Fig. 3M) after regeneration For conditions, see Fig. 3M.

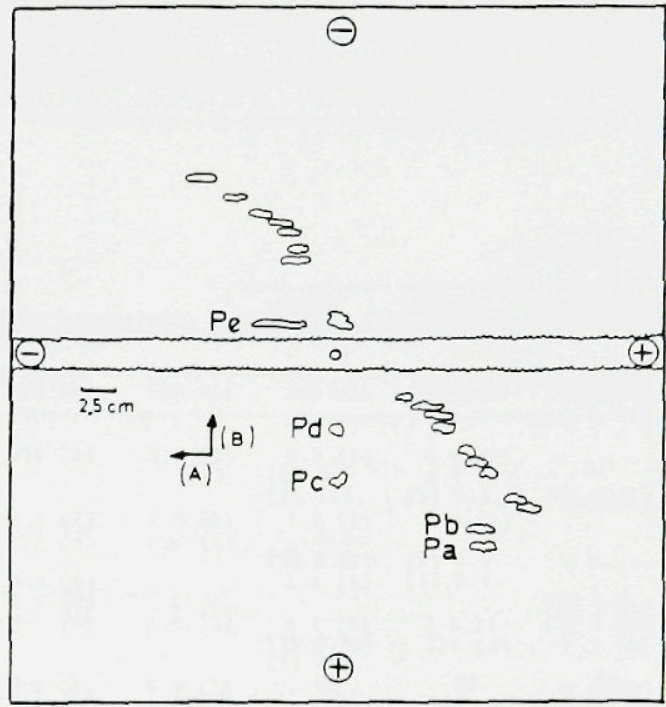

Fig. SM. Allocation of the disulfide bridges in the native protein. The protein was digested by pepsin and the digest submitted to analytic paper electrophoresis at $\mathrm{PH} 6.5$ in direction $A$. a second paper electrophoresis at the same $\mathrm{pH}$ in direction $B$. The peptides were detected by fluorescamine.

Table 1M. Oata on tryptic peptides of CB2. Figures in parentheses were obtained by sequencing. ND: not determined; i : ion-exchange chromatography; G50 : filtration on Sephadex G-50; G25 : filtration on Sephade G-25; P6 : filtration on Bio-Gel P6; P4 : filtration on Bio-Gel P4; (a) electrophoresis at $\mathrm{pH}^{3.5}$; C $\mathrm{C}$. descending paper chromatography:

\begin{tabular}{|c|c|c|c|c|c|}
\hline $\begin{array}{l}\text { Amino } \\
\text { acid }\end{array}$ & CB2T1 bca: & $C B 2 T 1 b \underline{c b}::$ & CB2T1 bdb:: & CB2T1 eea": & CB2T1 eeb:: \\
\hline $\begin{array}{l}\text { Lys } \\
\text { His }\end{array}$ & & & & $1.0\langle 1\rangle$ & $1.0\langle 1\rangle$ \\
\hline $\begin{array}{l}\text { His } \\
\text { Arg }\end{array}$ & $1.0 \quad(1)$ & 1.0 (1) & 1.0 (1) & & \\
\hline $\begin{array}{l}\text { CmCys } \\
\text { Asp }\end{array}$ & 0.3 (1) & 0.4 (1) & 0.5 (1) & & \\
\hline $\begin{array}{l}\text { Asp } \\
\text { Thr }\end{array}$ & 1.5 (1) & $4.6(5)$ & $4.7(5\}$ & 1.2 (1) & $1.6(2)$ \\
\hline $\begin{array}{l}\text { Thr } \\
\text { Ser }\end{array}$ & $\begin{array}{l}2.1 \\
3.9\end{array}\left(\begin{array}{l}2 \\
3.9\end{array}\right)$ & 2.1 (2) & $2.0(2)$ & $1.8(2)$ & $\begin{array}{l}1.0 \\
0.7\end{array}$ \\
\hline Glu & 2.0 (2) & $2.6 \quad(3)$ & $3.0(3)$ & 2.1 (2) & 1.2 (1) \\
\hline $\begin{array}{l}\text { Pro } \\
\text { Gly }\end{array}$ & & 0.3 (1) & $0.5(1)$ & $2.4(2)$ & 0.5 (1) \\
\hline $\begin{array}{l}\text { Gly } \\
\text { Ala }\end{array}$ & $\begin{array}{l}4.1 \\
1.2 \\
1.2\end{array}(1)$ & 1.2 (1) & 1.2 (1) & $\left.\begin{array}{l}4.6 \\
4.4(5) \\
4\end{array}\right)$ & $\begin{array}{l}2.9 \\
4.2(3)\end{array}$ \\
\hline Val & 1.0 (1) & 1.0 (1) & 1.1 (1) & 0.9 (1) & \\
\hline Ile & & 0.7 (1) & $0.8 \quad(1)$ & $1.0(1)$ & 0.8 (1) \\
\hline Leu & 1.3 (1) & $2.0 \quad(2)$ & $2.3 \quad(2\}$ & 1.1 (1) & 0.9 (1) \\
\hline Tyr & $0.7(1)$ & $1.4(2)$ & 1.3 (2) & 0.5 (1) & (1) \\
\hline Phe & & $1.0(1)$ & $1.1(1)$ & $1.1(1)$ & $1.3(2)$ \\
\hline $\begin{array}{l}\text { Trp } \\
\text { Hse }\end{array}$ & ND (1) & ND & ND & ND & ND \\
\hline $\begin{array}{l}\text { Mobility } \\
(\mathrm{pH} 6.5)\end{array}$ & -0.37 & -0.37 & -0.37 & 0.00 & 0.00 \\
\hline N-terminal & Asp & $11 e$ & Ile & Val & Phe \\
\hline Yield & $9.3 \%$ & $10.2 \%$ & $6.3 \%$ & $11.9 \%$ & $17.1 \%$ \\
\hline Position & $1 \rightarrow 20$ & $72 \rightarrow 92$ & $72 \rightarrow 92$ & $26 \rightarrow 47$ & $53 \rightarrow 71$ \\
\hline $\begin{array}{l}\text { Number of } \\
\text { residues }\end{array}$ & 20 & 21 & 21 & 22 & 19 \\
\hline $\begin{array}{l}\text { Procedure } \\
\text { of iso- } \\
\text { lation }\end{array}$ & $\begin{array}{c}625 ; 6.5 ; \\
3.5 ; C\end{array}$ & $\begin{array}{r}625 ; 6.5 \\
3.5 ; C\end{array}$ & $\begin{array}{c}\mathrm{G} 25 ; 6.5 ; \\
3.5 ; \mathrm{C}\end{array}$ & $\begin{array}{c}\mathrm{G} 25 ; 6.5 ; \\
3.5 ; \mathrm{C}\end{array}$ & $\begin{array}{c}625 ; 6.5 \\
3.5 ; C\end{array}$ \\
\hline
\end{tabular}


Table IM (continued a)

\begin{tabular}{|c|c|c|c|c|c|}
\hline $\begin{array}{l}\text { Amino } \\
\text { acid }\end{array}$ & CB2T1hb* & CB2T1he" & CB2T11 & $\mathrm{CB} 2 \mathrm{~T} 2 \mathrm{CC}$ & $\mathrm{CB} 2 \mathrm{~T} 2 \mathrm{fb} *$ \\
\hline $\begin{array}{l}\text { Lys } \\
\text { His }\end{array}$ & & & & 0.9 (1) & \\
\hline $\begin{array}{l}\text { Arg } \\
\text { Cacys }\end{array}$ & 0.9 (1) & & 0.8 (1) & & 0.8 (1) \\
\hline Asp & & 1.0 (1) & & $\begin{array}{l}0.3 \\
1.9\end{array}\left\{\begin{array}{l}1 \\
2\end{array}\right\}$ & \\
\hline Thr & $1.0(1)$ & 1.0 (1) & & & 1.1 (1) \\
\hline $\begin{array}{l}\text { Ser } \\
\text { Glu } \\
\text { Pro }\end{array}$ & $1.0\langle 1)$ & 0.4 & $1.3(1)$ & $1.7\langle 2\rangle$ & $1.1\{i\}$ \\
\hline $\begin{array}{l}\text { Gly } \\
\text { Ala }\end{array}$ & $3.2(3)$ & $2.3(2)$ & & $2.5(2)$ & \\
\hline $\begin{array}{l}\text { Val } \\
\text { lle }\end{array}$ & 0.9 (1) & 0.8 (1) & $\begin{array}{l}1.9 \\
1.1\end{array}\left(\begin{array}{l}2 \\
1\end{array}\right)$ & & $\begin{array}{l}2.9 \\
1.1\end{array}\left(\begin{array}{l}3 \\
1\end{array}\right)$ \\
\hline Leu & & 1.0 (1) & & & \\
\hline $\begin{array}{l}\text { Tyr } \\
\text { Phe }\end{array}$ & & & & & \\
\hline $\begin{array}{l}\text { Trp } \\
\text { Hse }\end{array}$ & NO & $\begin{array}{l}\text { No } \\
0.9 \text { (1) }\end{array}$ & NO & ND (1) & ND \\
\hline $\begin{array}{l}\text { Mobility } \\
(\mathrm{pH} 6.5)\end{array}$ & +0.43 & +0.43 & +0.48 & -0.24 & +0.46 \\
\hline $\mathrm{N}$-terminal & val & A la & Ala & CmCys & Val \\
\hline Yield & $10.7 \div$ & $2.1 \%$ & $5.1 \%$ & $6.1 \%$ & $3.4 x$ \\
\hline Position & $102 \rightarrow 108$ & $109 \rightarrow 115$ & $48 \div 52$ & $93 \rightarrow 101$ & $102 \rightarrow 108$ \\
\hline $\begin{array}{l}\text { Number of } \\
\text { residues }\end{array}$ & 7 & 7 & 5 & 9 & 7 \\
\hline $\begin{array}{l}\text { Procedure } \\
\text { of iso- } \\
\text { lation }\end{array}$ & $\begin{array}{l}G 25 ; 6.5 ; \\
C\end{array}$ & $\begin{array}{l}\mathrm{G} 25 ; 6.5 ; \\
\mathrm{C}\end{array}$ & $625 ; 6.5$ & $\begin{array}{l}625 ; 6.5: \\
3.5\end{array}$ & $\begin{array}{l}G 25 ; 6.5 ; \\
C\end{array}$ \\
\hline
\end{tabular}

Table IM (continued b)

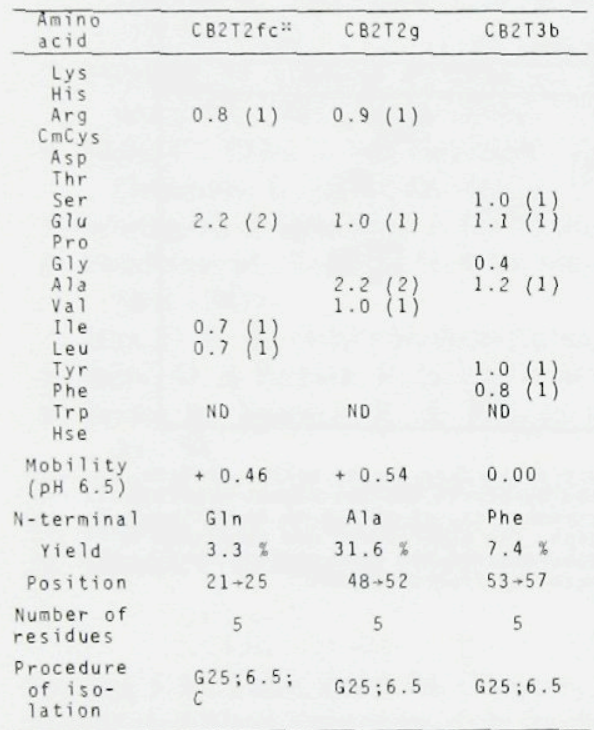

Table 2M. Data on chymotryptic peptides of CB2. For all details, see

\begin{tabular}{|c|c|c|c|c|c|c|}
\hline $\begin{array}{l}\text { Amino } \\
\text { acid }\end{array}$ & $C B 2 C 1 \mathrm{~b}$ & $\mathrm{CB} 2 \mathrm{C} 1 \mathrm{f} \underline{\mathrm{b}}$ & $C B 2 C 1 \mathrm{f} \underline{\mathrm{e}}$ & $\mathrm{CB} 2 \mathrm{Clh}$ & CB2C1ja: & $C B 2 C 1 n$ \\
\hline \multicolumn{7}{|l|}{$\begin{array}{l}\text { Lys } \\
\text { Hiss }\end{array}$} \\
\hline $\begin{array}{l}\text { His } \\
\text { Arg }\end{array}$ & & & 0.9 (1) & 1.0 (1) & & 1.0 (1) \\
\hline \multicolumn{7}{|c|}{$0.9(1)$} \\
\hline $\begin{array}{l}\text { Asp } \\
\text { Thr }\end{array}$ & $\begin{array}{l}3.7(4) \\
1.0(1)\end{array}$ & $\begin{array}{l}0.9 \\
0.7(1)\end{array}$ & & $\begin{array}{l}0.3 \\
0.7 \quad \text { (1) }\end{array}$ & 0.5 (1) & $\begin{array}{l}0.3 \\
1.0 \text { (1) }\end{array}$ \\
\hline ser & & & $2.8 \quad(3)$ & $2.4(4)$ & $1.3(2)$ & 0.3 \\
\hline $\begin{array}{l}\text { Glu } \\
\text { Pro }\end{array}$ & $\begin{array}{l}1.9(2) \\
1.1\end{array}$ & $0.9\langle 1\rangle$ & $2.9(3)$ & & & $\begin{array}{l}1.8(2) \\
1.2(1)\end{array}$ \\
\hline Gly & & $3.0(3)$ & 2.1 (2) & 2.2 (3) & 2.3 (2) & 3.1 (3) \\
\hline Ala & & $3.0(3)$ & $1.1(1)$ & 1.1 (1) & 2.1 (2) & $1.6 \quad 2)$ \\
\hline $\begin{array}{l}\text { Val } \\
\text { lle }\end{array}$ & $1.2\langle 1\rangle$ & $0.9 \quad(1)$ & & & & $\left.\begin{array}{l}1.1 \\
1.0\end{array}\right\}$ \\
\hline $\begin{array}{l}\text { Leu } \\
\text { Tyyr }\end{array}$ & $1.2(1)$ & $0.8(1)$ & $1.0(1)$ & $1.3(2)$ & & $1.0\} 1\}$ \\
\hline $\begin{array}{l}\text { Phe } \\
\text { Trp }\end{array}$ & 1.0 (1) & 0.8 (1) & & & & \\
\hline $\begin{array}{l}\text { Trp } \\
\text { Hse }\end{array}$ & NO & No & ND & ND & ND & NO \\
\hline $\begin{array}{l}\text { Mobility } \\
\text { (pH } 6.5 \text { ) }\end{array}$ & -0.74 & -0.28 & -0.28 & -0.17 & 0.00 & +0.24 \\
\hline$N$-termina 1 & Gin & G Iy & Ser & Ser & Ser & Gin \\
\hline Yield & $30.8 \%$ & $14.6 \%$ & $7.6 \%$ & $25.5 \%$ & $2.1 \%$ & $16.9 \%$ \\
\hline Position & $74 \rightarrow 85$ & $58 \rightarrow 69$ & $11 \rightarrow 22$ & $7 \rightarrow 22$ & $98 \rightarrow 106$ & $23 \rightarrow 36$ \\
\hline $\begin{array}{l}\text { Number of } \\
\text { residues }\end{array}$ & 12 & 12 & 12 & 16 & 9 & 14 \\
\hline $\begin{array}{l}\text { Procedure } \\
\text { of iso- } \\
\text { lation }\end{array}$ & $625 ; 6.5$ & $\begin{array}{l}\text { G25;6.5; } \\
3.5\end{array}$ & $\begin{array}{l}625 ; 6.5 ; \\
3.5\end{array}$ & $625 ; 6.5$ & ${ }_{C}^{G 25 ; 6.5 ;}$ & $625 ; 6.5$ \\
\hline
\end{tabular}

Table $2 M$ (continued a)

\begin{tabular}{|c|c|c|c|c|c|c|}
\hline $\begin{array}{l}\text { Amino } \\
\text { acid }\end{array}$ & $\mathrm{CB} 2 \mathrm{C} 1 \mathrm{qb})$ & $\mathrm{CB} 2 \mathrm{C} 1 \mathrm{qC} "$ & $\mathrm{CB} 2 \mathrm{C} 1 \mathrm{rg} "$ & $\mathrm{CB} 2 \mathrm{C} 1 \mathrm{~s}$ & CB2C1ta" & $\mathrm{CB} 2 \mathrm{C} 2 \mathrm{C}$ \\
\hline Lys & & $1.0(1)$ & & $1.0(1)$ & & \\
\hline $\begin{array}{l}\mathrm{His} \\
\mathrm{Arg}\end{array}$ & 0.9 (1) & & & 0.4 & 1.1 (1) & \\
\hline $\begin{array}{c}\text { CmCys } \\
\text { Asp }\end{array}$ & & & & & & \\
\hline $\begin{array}{l}\text { Asp } \\
\text { Thr }\end{array}$ & $\begin{array}{l}0.9 \\
0.9\end{array}\left\{\begin{array}{l}1 \\
1\end{array}\right\}$ & $\begin{array}{l}0.1 \\
0.7\end{array}$ & 0.4 (1) & $\begin{array}{l}0.3 \\
1.2 \quad(1)\end{array}$ & $1.3(1)$ & \\
\hline $\begin{array}{l}\text { Ser } \\
\text { Glu }\end{array}$ & & 0.4 & & $1.2(1)$ & & \\
\hline $\begin{array}{l}\text { Glu } \\
\text { Pro }\end{array}$ & & $\left.\left.\begin{array}{l}0.9 \\
1.0\end{array}\right\} \begin{array}{l}1 \\
1\end{array}\right\}$ & & 1.0 (1) & & 1.0 (1) \\
\hline Gly & 0.3 & $1.3 \backslash 1\}$ & & $1.1 \backslash 1\}$ & 0.3 & \\
\hline $\begin{array}{l}\text { Ala } \\
\text { Val }\end{array}$ & $2.3(2)$ & $2.8\langle 3\}$ & $1.1 \quad(1)$ & $2.9(3)$ & 1.4 (2) & 1.0 (1) \\
\hline $\begin{array}{l}\text { Va } 1 \\
\text { Ile }\end{array}$ & & $1.0\langle 1\}$ & $1.0(1)$ & 0.2 & & 0.1 \\
\hline $\begin{array}{l}\text { Leu } \\
\text { Tyr }\end{array}$ & & & 1.0 (1) & & & 1.0 (1) \\
\hline $\begin{array}{l}\text { Phe } \\
\text { Trp }\end{array}$ & ND & ND & & & 10 & 00 \\
\hline $\begin{array}{l}\text { Trp } \\
\text { Hse }\end{array}$ & ind & & 0,4 (1) & No & & \\
\hline $\begin{array}{l}\text { Mobtlity } \\
\text { (pH 6.5) }\end{array}$ & +0.45 & +0.45 & +0.52 & +0.57 & +0.60 & -0.55 \\
\hline N-terminal & Thr & Gly & Ala & G1y & $A l a$ & Ala \\
\hline Yield & $7.7 \%$ & $10.0 \%$ & $2.9 \%$ & $10.2 \%$ & $2.3 \%$ & $14.2 \%$ \\
\hline Position & $106+110$ & $43 \div 51$ & $111+115$ & $43 \div 49$ & $107+110$ & $88 \rightarrow 90$ \\
\hline $\begin{array}{l}\text { Number of } \\
\text { residues }\end{array}$ & 5 & 9 & 5 & 7 & 4 & 3 \\
\hline $\begin{array}{l}\text { Procedure } \\
\text { of iso- } \\
\text { lation }\end{array}$ & $\begin{array}{l}G 25 ; 6.5 ; \\
C\end{array}$ & $625 ; 6.5 ;$ & $\begin{array}{l}\mathrm{G} 25 ; 6.5 ; \\
\mathrm{C}\end{array}$ & G25;6.5 & $\begin{array}{l}G 25 ; 6.5 ; \\
C\end{array}$ & $625 ; 6.5$ \\
\hline
\end{tabular}

Table $2 M$ (continued b)

\begin{tabular}{|c|c|c|c|c|c|c|}
\hline $\begin{array}{l}\text { Amino } \\
\text { acid }\end{array}$ & CB2C2f & $C B 2 C 21$ & $C B 2 C 3 a$ & $C B 2 C 3 b$ & $C B 2 C 3 d$ & $C 82 C 3 \mathrm{e}$ \\
\hline \multirow{11}{*}{$\begin{array}{l}\text { Lys } \\
\text { His } \\
\text { Arg } \\
\text { CmCys } \\
\text { Asp } \\
\text { Thr } \\
\text { Ser } \\
\text { Glu } \\
\text { Pro } \\
\text { Gly } \\
\text { Ala } \\
\text { Val } \\
\text { Ile } \\
\text { Leu } \\
\text { Tyr } \\
\text { Phe } \\
\text { Trp } \\
\text { Hse }\end{array}$} & 0.4 & 1.2 (1) & & & & \\
\hline & & & & 0.6 (1) & & \\
\hline & & & 0.5 (1) & 0.4 (1) & & \\
\hline & $\begin{array}{l}1.0 \\
0.1\end{array}$ & 1.1 (1) & 0.9 (1) & 2.8 (3) & & 1.0 (1) \\
\hline & $\begin{array}{l}0.2 \\
1.0(1)\end{array}$ & & & $\left.\begin{array}{l}0.6(1) \\
0.9(1)\end{array}\right)$ & $\left.\begin{array}{l}0.9(1) \\
1.2(1)\end{array}\right)$ & $\begin{array}{l}0.1 \\
1.3 \text { (1) }\end{array}$ \\
\hline & 1.0 (1) & & 1.2 (1) & 0.5 & & 0.9 (1) \\
\hline & $1.0\langle 1\rangle$ & & & 1.1 (1) & $1.2\langle 1\rangle$ & $1.0\langle 1\rangle$ \\
\hline & 1.1 (1) & 0.9 (1) & & & & 0.9 (1) \\
\hline & & $0 \quad 8 \quad(1)$ & 10 (1) & $1.3(1)$ & $07(1)$ & $\begin{array}{l}0.4 \\
0.3\end{array}$ \\
\hline & 0.9 (1) & 0.8 (1) & $1.0(1)$ & & 0.1 (1) & 0.9 (1) \\
\hline & ND & ND & ND & NO (1) & ND & ND \\
\hline $\begin{array}{l}\text { Mobility } \\
(\mathrm{pH} 6.5)\end{array}$ & -0.38 & +0.37 & -0.90 & -0.64 & -0.53 & -0.37 \\
\hline$N$-terminal & Ala & Asn & Asp & Ala & $G 1 n$ & Ala \\
\hline Yield & $16.0 \%$ & $9.6 \%$ & $29.5 \%$ & $2.8 \%$ & $6.8 \%$ & $20.8 \%$ \\
\hline Position & $37 \div 42$ & $70 \rightarrow 73$ & $1+4$ & $88 \rightarrow 97$ & $54 \div 57$ & $37 \rightarrow 42$ \\
\hline $\begin{array}{l}\text { Number of } \\
\text { residues }\end{array}$ & 6 & 4 & 4 & 10 & 4 & 6 \\
\hline $\begin{array}{l}\text { Procedure } \\
\text { of iso- } \\
\text { lation }\end{array}$ & $625 ; 6.5$ & G25; 6.5 & G25;6.5 & $625 ; 6.5$ & G25;6.5 & $\mathrm{G} 25 ; 6.5$ \\
\hline
\end{tabular}


Table 3M. Data on Armillaria mellea digest of CB2. For all details,

\begin{tabular}{|c|c|c|c|c|c|c|}
\hline $\begin{array}{l}\text { Amino } \\
\text { acid }\end{array}$ & CB 2 AM $2 \mathrm{a}$ & CВ $2 A M 2 \mathrm{~b}$ & CB2AM2d & C В 2 AM $2 \mathrm{e}$ & CB2AM $2 f$ & С В2АМЗ \\
\hline $\begin{array}{l}\text { Lys } \\
\text { His }\end{array}$ & $0.8 \quad(1)$ & 0.6 & 0.7 (1) & $1.3(1)$ & $1.3(1)$ & $0.8 \quad(1)$ \\
\hline $\begin{array}{c}\text { Arg } \\
\text { Cacys }\end{array}$ & $\begin{array}{l}0.9 \\
1.4\end{array}\left\{\begin{array}{l}1 \\
2\end{array}\right\}$ & $\begin{array}{l}1.8 \\
0.5\end{array}\left\{\begin{array}{l}2 \\
1\end{array}\right\}$ & 0.7 (1) & 0.9 (1) & $1.3(1)$ & $1.0 \quad(1)$ \\
\hline $\begin{array}{l}\text { Asp } \\
\text { Thr }\end{array}$ & $\left.\left.\begin{array}{l}7.2 \\
2.2\end{array}\right\} \begin{array}{l}7 \\
2\end{array}\right\}$ & $\left.\begin{array}{l}4.2 \\
5.2\end{array}\right\}$ & $\begin{array}{l}1.9 \\
1.0\end{array}\left(\begin{array}{l}2 \\
1\end{array}\right\}$ & $\begin{array}{l}1.1 \\
2.1\end{array}\left\{\begin{array}{l}1 \\
2\end{array}\right\}$ & $\begin{array}{l}1.0 \\
1.5\end{array}\left\{\begin{array}{l}1 \\
2\end{array}\right\}$ & $\begin{array}{r}1.8 \\
0.9\end{array}\left(\begin{array}{l}2 \\
1\end{array}\right)$ \\
\hline Ser & 1.832 & $4.8\} 4$ & $0.9\} 1$ & $1.0\{1\}$ & $0.9\{1\}$ & $0.9\{1\}$ \\
\hline $\begin{array}{l}\text { Glu } \\
\text { Pro }\end{array}$ & $\begin{array}{l}2.9 \\
0.7\end{array}\left(\begin{array}{l}3 \\
1\end{array}\right\}$ & $\left.\left.\begin{array}{l}6.0 \\
1.4\end{array}\right\} \begin{array}{l}6 \\
2\end{array}\right\}$ & $\left.\left.\begin{array}{l}1.8 \\
0.7\end{array}\right\} \begin{array}{l}2 \\
1\end{array}\right\}$ & & & $\begin{array}{l}1.8 \\
0.7\end{array}$ \\
\hline 6) $y$ & 1.8 (2) & $8.1 \backslash 9\}$ & $2.5(3\}$ & 0.2 & 0.3 & $2.6(3)$ \\
\hline Alá & 1.0 (1) & $5.6\langle 5\}$ & $6.3\langle 6\}$ & $4.6 \quad(5)$ & 5.0 (5) & $6.3(6)$ \\
\hline val & $1.0\{1\}$ & $2.2(2)$ & $\left.\begin{array}{l}1.0 \\
0\end{array}\right\}$ & $2.1(2)$ & $1.9(2\}$ & 1.2 (1) \\
\hline $\begin{array}{l}\text { Ile } \\
\text { Leu }\end{array}$ & $1.7\left\{\begin{array}{l}1 \\
2\end{array}\right\}$ & $\begin{array}{l}1.7 \\
3.0\end{array}\left(\begin{array}{l}2 \\
3\end{array}\right)$ & $\left.\begin{array}{l}0.8 \\
0.9(1) \\
1\end{array}\right)$ & $0.9\langle 1\}$ & $100\{1\}$ & $0.9\{1\}$ \\
\hline Tyr & $1.5\{2\}$ & $1.6(2)$ & 0.7 (1) & $0.9(1)$ & $1.0(1)$ & $1.0\{1\}$ \\
\hline phe & 0.9 (1) & 1.2 (i) & 1.5 (2) & & & 1.8 (2) \\
\hline $\begin{array}{l}\text { Trp } \\
\text { Hse }\end{array}$ & No (1) & ND (1) & NO & $\begin{array}{l}\text { ND } \\
0.3 \text { (1) }\end{array}$ & $\begin{array}{l}\text { No } \\
0.7 \text { (1) }\end{array}$ & ND \\
\hline $\begin{array}{l}\text { Mobility } \\
\text { (pH } 6.5)\end{array}$ & -0.55 & -0.22 & +0.17 & +0.45 & +0.65 & +0.17 \\
\hline$N$-termina 1 & Lys & Asn & Lys & Lys & Lys & Lys \\
\hline Yield & $12.3 \mathrm{~g}$ & 0.5 \& & 43.62 & 1.12 & $0.4 \%$ & 16.66 \\
\hline Position & $71+100$ & $1 \rightarrow 46$ & $47 \rightarrow 70$ & $101+115$ & $101+115$ & $47 \rightarrow 70$ \\
\hline $\begin{array}{l}\text { Number of } \\
\text { residues }\end{array}$ & 30 & 46 & 24 & 15 & 15 & 24 \\
\hline $\begin{array}{l}\text { Procedure } \\
\text { of iso- } \\
\text { lation }\end{array}$ & $650: 6.5$ & G50 50.5 & $650 ; 6.5$ & $650 ; 6.5$ & $650 ; 6.5$ & G50 \\
\hline
\end{tabular}

Table 4M. Oata on Staphyzococcus aureus protease digest of CBzaMza

\begin{tabular}{|c|c|c|}
\hline $\begin{array}{l}\text { Amino } \\
\text { acid }\end{array}$ & CB2AM $2 a S A a$ & CBIAM $2 \mathrm{a} S A \mathrm{~b}$ \\
\hline \multirow{2}{*}{$\begin{array}{l}\text { Lys } \\
\text { His } \\
\text { Arg }\end{array}$} & 1.0 (1) & \\
\hline & & $1.0 \quad(1)$ \\
\hline Concys & 0.5 (1) & 0.6 (1) \\
\hline \multirow{2}{*}{$\begin{array}{l}\text { Asp } \\
\text { Thr }\end{array}$} & $\begin{array}{l}3.9 \\
1.9\end{array}\left(\begin{array}{l}4 \\
3\end{array}\right)$ & \\
\hline & & 1.3 (2) \\
\hline Glu & 3.1 (3) & \\
\hline \multirow{2}{*}{ Gly } & 1.0 (1) & \\
\hline & 1.0 (1) & $1.9(2)$ \\
\hline $\begin{array}{l}\text { Ala } \\
\text { val }\end{array}$ & 0.8 (1) & \\
\hline Ile & 1.0 (i) & \\
\hline \multirow{2}{*}{ Tyr } & 1.4 (1) & 0.9 (1) \\
\hline & 2.0 (2) & \\
\hline $\begin{array}{l}\text { Phe } \\
\text { Trp }\end{array}$ & $\begin{array}{l}0.8 \quad(1) \\
\text { ND }\end{array}$ & ND (1) \\
\hline \multicolumn{3}{|l|}{ Hse } \\
\hline 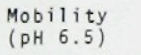 & -0.35 & -0.18 \\
\hline $\mathrm{N}$-terminal & Lys & Leu \\
\hline Yield & $31.9 \%$ & $40.8 \%$ \\
\hline Position & $71 \rightarrow 89$ & $90 \rightarrow 100$ \\
\hline Number of & 19 & 11 \\
\hline $\begin{array}{l}\text { Procedure } \\
\text { of iso- } \\
\text { lation }\end{array}$ & 6.5 & 6.5 \\
\hline
\end{tabular}

Table 5M. Time course of degradation of $10 \mathrm{nmol}$ of CB2AM2aSAa (71-89)

by carboxypeptidase $Y$

\begin{tabular}{|c|c|c|c|c|c|c|}
\hline & Amount & $t$ of & amino & $a c i d r e$ & sidue & released: \\
\hline Time & Asn & Phe & Thr & Tyr & Ala & G1u \\
\hline $\min$ & nmol & nmol & $\mathrm{nmol}$ & $\mathrm{nmol}$ & $\mathrm{nmol}$ & $\mathrm{nmol}$ \\
\hline $\begin{array}{r}0 \\
10 \\
20 \\
40 \\
60\end{array}$ & $\begin{array}{l}0.00 \\
0.00 \\
0.00 \\
0.00 \\
0.00\end{array}$ & $\begin{array}{l}0.00 \\
0.00 \\
0.25 \\
0.81 \\
0.94\end{array}$ & $\begin{array}{l}0.00 \\
0.49 \\
0.81 \\
1.03 \\
1.02\end{array}$ & $\begin{array}{l}0.00 \\
0.53 \\
0.84 \\
0.95 \\
0.94\end{array}$ & $\begin{array}{l}0.00 \\
0.66 \\
0.74 \\
1.03 \\
1.00\end{array}$ & $\begin{array}{l}0.00 \\
0.95 \\
1.00 \\
1.07 \\
1.09\end{array}$ \\
\hline
\end{tabular}

Table 6M. Data on tryptic peptides of CB3. For all detalls, see

\begin{tabular}{|c|c|c|c|c|c|c|c|}
\hline $\begin{array}{l}\text { Anino } \\
\text { acid }\end{array}$ & C83T1d & СвзТ1h & CB3T11 & CB3T1j & Cв3T2a & CВ3T2b & C83T2e \\
\hline $\begin{array}{l}\text { Lys } \\
\text { His }\end{array}$ & 1.1 (1) & $0.9(1)$ & $3.4(4)$ & $4.0 \quad(4)$ & & & $0.6 \quad(1)$ \\
\hline $\begin{array}{c}\text { Arg } \\
\text { CmCys }\end{array}$ & 0.2 & $\left.\left.\begin{array}{l}1.1 \\
0\end{array}\right\} 1\right\}$ & $1.4\{1\}$ & $1.4\{1\}$ & & & \\
\hline Asp & $\begin{array}{ll}0.5 & 1 \\
1.1 & (1)\end{array}$ & $\left.\begin{array}{l}0.0 \\
1.0\end{array}\right\}$ & 3.9 (4) & 3.9 (4) & $0.7 \quad(1)$ & $0.6(1)$ & \\
\hline $\begin{array}{l}\text { Thr } \\
\text { Ser }\end{array}$ & 0.2 & & $1.9\{2\}$ & $1.8\{2\}$ & & & \\
\hline $\begin{array}{l}\text { Ser } \\
\text { Glus }\end{array}$ & $\begin{array}{l}0.9 \\
1.2\end{array}\left\{\begin{array}{l}1 \\
1\end{array}\right\}$ & $\left.\left.\begin{array}{l}0.6 \\
1.4\end{array}\right\} \begin{array}{l}1 \\
2 \\
2\end{array}\right\}$ & $1.3\langle 1\}$ & $0.9\langle 1\}$ & $2.1 \quad(2)$ & $1.9(2)$ & \\
\hline $\begin{array}{l}\text { Pro } \\
\text { Gly }\end{array}$ & & & $1.7(2$ & $\begin{array}{l}1.9 \\
1.9\end{array}$ & 0.9 & 1.1 (1) & \\
\hline $\begin{array}{l}\text { Gly } \\
\text { Ala }\end{array}$ & $2.3(4)$ & $2.8 \quad(4)$ & $6.3\langle 7$ & $6.5) 7$ & $1.3) 1$ & $1.2(1)$ & $1.0 \quad(1)$ \\
\hline $\begin{array}{l}\text { Ala } \\
\text { Val }\end{array}$ & $3.6(4)$ & $4.9(7)$ & $1.0(1)$ & $1.0\}$ & $1.1(1)$ & 1.2 (1) & \\
\hline $\begin{array}{l}\text { Ile } \\
\text { Leu }\end{array}$ & 0.5 & & $\left.\begin{array}{l}1.2 \\
0.9(1)\end{array}\right)$ & $\begin{array}{l}1.0 \\
1.0 \\
1\end{array}$ & $0.8 \quad(1)$ & 1.0 (1) & \\
\hline $\begin{array}{l}\text { Leu } \\
\text { Tyr }\end{array}$ & 1.1 (1) & $2.3 \quad(2)$ & $0.9\langle 1\rangle$ & 0.9 (1) & & & \\
\hline $\begin{array}{l}\text { Tyr } \\
\text { Phe }\end{array}$ & $0.3\langle 1\}$ & $1.0\langle 1\rangle$ & $0.6\{1\}$ & $0.5\langle 1\rangle$ & & & $0.6(1)$ \\
\hline $\begin{array}{l}\text { Phe } \\
\text { Trp }\end{array}$ & 0.6 (1) & $1.3(1)$ & $0.9(1)$ & 0.8 (1) & $0.8 \quad(1)$ & 1.0 (1) & \\
\hline $\begin{array}{l}\text { Trp } \\
\text { Hse }\end{array}$ & ND & ND & ND & NO & ND (1) & ND (1) & ND \\
\hline $\begin{array}{l}\text { Mobility } \\
(\mathrm{pH} \\
\text { 6.5 }\end{array}$ & -0.25 & -0.06 & 0.00 & +0.29 & -0.51 & -0.19 & +0.53 \\
\hline$N$-terminal & Tyr & Tyr & Asn & Asn & Phe & Phe & Tyr \\
\hline Yie1d & $6.2 \%$ & $24.2 \%$ & $11.4 \%$ & $21.8 \%$ & $1.6 \%$ & $12.9 \%$ & $2.4 \%$ \\
\hline Position & $155+170$ & $155-176$ & $177+203$ & $177+203$ & $204+212$ & $204+212$ & $155 \div 157$ \\
\hline $\begin{array}{l}\text { Number of } \\
\text { residues }\end{array}$ & 16 & 22 & 27 & 27 & 9 & 9 & 3 \\
\hline $\begin{array}{l}\text { Procedure } \\
\text { of iso- } \\
\text { lation }\end{array}$ & $625 ; 6.5$ & G25;6.5 & $625 ; 6.5$ & G $25 ; 6.5$ & $625 ; 6.5$ & $625 ; 6.5$ & $625 ; 6.5$ \\
\hline
\end{tabular}

Table 7M. Data on thermolytic peptides of CB3. For all details, see

\begin{tabular}{|c|c|c|c|c|c|}
\hline $\begin{array}{l}\text { Amino } \\
\text { acid }\end{array}$ & CB3TH1C & CB3 TH1 e & $\mathrm{CB} 3 \mathrm{TH}^{2 \mathrm{e}}$ & C83TH21 & CB3TH3ad: \\
\hline \multirow{9}{*}{$\begin{array}{l}\text { Lys } \\
\text { His } \\
\text { Arg } \\
\text { CmCys } \\
\text { Asp } \\
\text { Thr } \\
\text { Ser } \\
\text { Glu } \\
\text { Pro } \\
\text { Gly } \\
\text { Ala } \\
\text { Val } \\
\text { Ile } \\
\text { Leu } \\
\text { Tyr } \\
\text { Phe } \\
\text { Trp }\end{array}$} & $2.8(3)$ & $3.3(3)$ & $0.9(1)$ & $\begin{array}{l}0.9 \\
0.9(1)\end{array}$ & \\
\hline & $\begin{array}{ll}2.2 & (2) \\
1.7 & (2)\end{array}$ & $\begin{array}{l}2.0(2) \\
1.2(1)\end{array}$ & $1.0 \quad(1)$ & 1.0 (1) & $0.5(1)$ \\
\hline & 0.9 (1) & & $\begin{array}{l}0.9 \\
1.2\end{array}\left(\begin{array}{l}1 \\
1\end{array}\right)$ & & $1.4(2)$ \\
\hline & $1.9\{2\}$ & $2.1 \quad$ (2) & & & $0.9(1)$ \\
\hline & $3.3(3)$ & $3.3(3)$ & $\left.\begin{array}{l}4.1 \\
3.0\end{array} \quad \begin{array}{l}4 \\
3\end{array}\right\}$ & $\begin{array}{l}1.0 \\
1.6(1)\end{array}$ & $\begin{array}{l}1.5 \\
1.2\{1\}\end{array}$ \\
\hline & 0.8 (1) & 0.9 (1) & & & 0.9 (1) \\
\hline & $\left.\begin{array}{l}0.8 \\
0.9\end{array}\right\}$ & 0.8 (1) & 1.3 (1) & & \\
\hline & 0.6 (i) & & & & \\
\hline & ND & ND & NO & ND & ND \\
\hline $\begin{array}{l}\text { Mobility } \\
(\mathrm{pH} 6.5)\end{array}$ & +0.13 & +0.38 & 0.00 & +0.81 & -0.37 \\
\hline $\mathrm{N}$-terminal & Phe & Ile & Tyr & Ala & Ser \\
\hline Yield & $1.6 \%$ & $15.7 \%$ & $1.9 \%$ & $7.7 \%$ & $2.2 \%$ \\
\hline Position & $180 \rightarrow 196$ & $183+196$ & $155 \rightarrow 1 \underline{6} 7$ & $174 \rightarrow 179$ & $206+212$ \\
\hline $\begin{array}{l}\text { Number of } \\
\text { residues }\end{array}$ & 17 & 14 & 13 & 6 & 7 \\
\hline $\begin{array}{l}\text { Procedure } \\
\text { of iso- } \\
\text { lation }\end{array}$ & $625 ; 6.5$ & $625 ; 6.5$ & $625 ; 6.5$ & G25; 6.5 & ${ }_{C}^{G 25 ; 6.5 ;}$ \\
\hline
\end{tabular}

\begin{tabular}{|c|c|c|c|c|c|}
\hline $\begin{array}{l}\text { Amino } \\
\text { acid }\end{array}$ & CВзТн3 ba: & CB3TH3Cf & C83TH4 ed": & CB3TH4 ef: & CB3TH5b \\
\hline \\
\hline & \multirow{3}{*}{$0.3(1)$} & & $0.7 \quad(1)$ & & \multirow[b]{4}{*}{$1.0(1)$} \\
\hline $\begin{array}{c}\text { Arg } \\
\text { CmCys }\end{array}$ & & $0.9(1)$ & & & \\
\hline Asp & & 1.0 (1) & 1.0 (1) & & \\
\hline $\begin{array}{l}\text { Thr } \\
\text { Ser }\end{array}$ & 0.8 (1) & & & & \\
\hline Glu & 0.9 (1) & & & 1.1 (1) & 1.1 (1) \\
\hline $\begin{array}{l}\text { Pro } \\
\text { Gly }\end{array}$ & $3.0(3)$ & $3.0 \quad(3)$ & 1.3 (1) & & \\
\hline $\begin{array}{l}\text { Ala } \\
\text { Val }\end{array}$ & $2.0\langle 2\rangle$ & $\left.\begin{array}{l}1.2\{1\} \\
0.9 \\
1\end{array}\right\}$ & $1.7(2)$ & $1.0(1)$ & \\
\hline Ile & & & & & \\
\hline Leu & 0.7 (1) & & & $1.0(1)$ & \\
\hline $\begin{array}{l}\text { Tyr } \\
\text { Phe }\end{array}$ & $0.8 \quad(1)$ & & 0.7 (1) & & 0.9 (1) \\
\hline Trp & ND & ND & ND & ND & ND \\
\hline 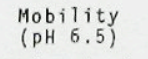 & -0.29 & 0.00 & 0.00 & 0.00 & -0.52 \\
\hline $\mathrm{N}$-terminal & Leu & Val & Tyr & Leu & Phe \\
\hline Yield & $2.1 \%$ & $9.0 \%$ & $4.2 \%$ & $10.7 \%$ & $8.1 \%$ \\
\hline Position & $161+170$ & $197+203$ & $155+160$ & $171 \rightarrow 173$ & $180 \rightarrow 182$ \\
\hline $\begin{array}{l}\text { Number of } \\
\text { residues }\end{array}$ & 10 & 7 & 6 & 3 & 3 \\
\hline $\begin{array}{l}\text { Procedure } \\
\text { of iso- } \\
\text { lation }\end{array}$ & $\begin{array}{l}G 25 ; 6.5 ; \\
C\end{array}$ & $\begin{array}{l}625 ; 6.5 ; \\
3.5\end{array}$ & ${ }_{C}^{G 25 ; 6.5 ;}$ & ${ }_{\mathrm{C}}^{\mathrm{G} 25 ; 6.5 ;}$ & $625 ; 6.5$ \\
\hline
\end{tabular}


Table 8M. Data on Staphyzeogooua aureun protease digest of CB3. For

\begin{tabular}{|c|c|c|c|c|c|}
\hline $\begin{array}{l}\text { Anino } \\
\text { acid }\end{array}$ & CB3SA1 a & CB3SAlbe" & CB3SA $2 a b=$ & CB3SA 2C & CB3SA2d \\
\hline \multicolumn{6}{|l|}{ Lys } \\
\hline His & $2.0(2)$ & $3.1(3)$ & \multirow{4}{*}{$0.6(1)$} & \multirow{4}{*}{$0.4 \quad(1)$} & 0.9 (1) \\
\hline $\begin{array}{c}\text { Arg } \\
\text { Cacys }\end{array}$ & 1.2 (1) & 1.0 i) & & & \\
\hline $\begin{array}{c}\text { Camcys } \\
\text { Asp }\end{array}$ & $0.5\{1\}$ & $0.5(1)$ & & & $0.7 \quad(1)$ \\
\hline $\begin{array}{l}\text { Asp } \\
\text { Ther }\end{array}$ & $\begin{array}{l}2.0 \\
1.2\end{array}\left(\begin{array}{l}2 \\
1\end{array}\right)$ & $\left.\begin{array}{l}2.8 \\
0.8\end{array}\right\}$ & & & $1.2(1)$ \\
\hline Ser & $1.3\left\{\begin{array}{l}1 \\
1\end{array}\right\}$ & $\left.\begin{array}{l}0.9 \\
1.6\end{array}\right\}$ & \multirow{2}{*}{0.8 (1) } & \multirow{2}{*}{$\begin{array}{l}0.9 \\
1.3\end{array}\left\{\begin{array}{l}1 \\
1\end{array}\right\}$} & \multirow{2}{*}{$\begin{array}{l}0.9 \\
1.2\end{array}\left(\begin{array}{l}1 \\
1\end{array}\right)$} \\
\hline $\begin{array}{l}\text { Glu } \\
\text { Pro }\end{array}$ & $3,2\{3\}$ & 0.2 & & & \\
\hline $\begin{array}{l}\text { Pro } \\
\text { Gly }\end{array}$ & $4.9 \quad(5)$ & $\begin{array}{r}3.0 \\
7.1\end{array}\left\{\begin{array}{l}3 \\
7\end{array}\right\}$ & \multirow{3}{*}{$\begin{array}{l}0.5 \\
1.2 \\
0.8\end{array}\left\{\begin{array}{l}1 \\
1 \\
1\end{array}\right\}$} & \multirow{3}{*}{$\begin{array}{l}2.9 \\
3.1\end{array}\left\{\begin{array}{l}2 \\
3\end{array}\right\}$} & \multirow{3}{*}{$\begin{array}{r}3.9 \\
4.0\end{array}\left\{\begin{array}{l}4 \\
4\end{array}\right\}$} \\
\hline Ala & $6.2\{7\}$ & $2.3\{2\}$ & & & \\
\hline $\begin{array}{l}\text { Val } \\
\text { Ile }\end{array}$ & & $0.7\} 1\}$ & & & \\
\hline $\begin{array}{l}\text { Ile } \\
\text { Leu }\end{array}$ & & $1.7\} 2\}$ & \multirow[t]{2}{*}{0.8 (1) } & & \\
\hline $\begin{array}{l}\text { Leu } \\
\text { Tyr }\end{array}$ & $1.8(2)$ & $0.8 \quad 11\}$ & & $1.0(1)$ & $1.6(2)$ \\
\hline Phe & $\begin{array}{l}0.8 \\
2.3\end{array}\left\{\begin{array}{l}1 \\
2\end{array}\right\}$ & $\left.\left.\begin{array}{l}0.3 \\
0.5\end{array}\right\} 1\right\}$ & \multirow{3}{*}{ ND } & $0.9\langle 1\rangle$ & $\left.\left.\begin{array}{l}0,6 \\
1,1\end{array}\right\} \begin{array}{l}1 \\
1\end{array}\right\}$ \\
\hline Trp & NO & No $\{1\}$ & & ND & \multirow{2}{*}{ ND } \\
\hline Hse & & & & & \\
\hline $\begin{array}{l}\text { Mobility } \\
(\mathrm{pH} 6.5)\end{array}$ & 0.00 & +0.08 & -0.48 & -0.28 & -0.25 \\
\hline $\mathrm{N}$-terminal & Tyr & tle & Ala & Ala & Tyr \\
\hline Yield & $21.9 \mathrm{z}$ & $4 x$ & $3.9 \%$ & $2.5 \%$ & $2.2 x$ \\
\hline Position & $155 \rightarrow 182$ & $183 \rightarrow 212$ & $207+212$ & $163 \rightarrow 172$ & $155 \rightarrow 171$ \\
\hline $\begin{array}{l}\text { Number of } \\
\text { residues }\end{array}$ & 28 & 30 & 6 & 10 & 17 \\
\hline $\begin{array}{l}\text { Procedure } \\
\text { of iso- } \\
\text { lation }\end{array}$ & $P 4: 6.5$ & $\begin{array}{l}P 4 ; 6.5 ; \\
C\end{array}$ & $\begin{array}{l}P 4 ; 6.5 ; \\
C\end{array}$ & $P 4 ; 6.5$ & $P 4 ; 6.5$ \\
\hline
\end{tabular}

Table 8M (continued a)

\begin{tabular}{|c|c|c|c|}
\hline $\begin{array}{l}\text { Amino } \\
\text { acid }\end{array}$ & CB3SA2ea: & CB3SA2 eb: & $C B 35 A 3 a$ \\
\hline \multirow{13}{*}{$\begin{array}{l}\text { Lys } \\
\text { His } \\
\text { Arg } \\
\text { CmCys } \\
\text { Asp } \\
\text { Thr } \\
\text { Ser } \\
\text { Glu } \\
\text { Pro } \\
\text { Gly } \\
\text { Ald } \\
\text { Val } \\
\text { Ile } \\
\text { Leu } \\
\text { Tyr } \\
\text { Phe } \\
\text { Trp } \\
\text { Hse }\end{array}$} & $0.8 \quad(1)$ & \multirow[t]{2}{*}{0.6 (1) } & \multirow[t]{2}{*}{1.1 (1) } \\
\hline & 0.9 (1) & & \\
\hline & 1.3 (1) & \multirow[t]{4}{*}{1.1 (1) } & \multirow[t]{4}{*}{1.2 (1) } \\
\hline & & & \\
\hline & 0.8 (i) & & \\
\hline & $\begin{array}{l}2.6 \quad(3) \\
0.1\end{array}$ & & \\
\hline & 2.3 (2) & \multirow{3}{*}{$\begin{array}{ll}2.8 & (3) \\
2.8 & (3)\end{array}$} & \multirow{3}{*}{$\begin{array}{l}2.6\left(\begin{array}{l}3 \\
2.7 \\
3\end{array}\right)\end{array}$} \\
\hline & $3.7(4)$ & & \\
\hline & & & \\
\hline & 0.9 (1) & \multirow{2}{*}{$\begin{array}{l}1.0 \\
0.5(1)\end{array}$} & \multirow{2}{*}{$\begin{array}{l}1.1 \\
0.9\end{array}\left(\begin{array}{l}1 \\
1\end{array}\right)$} \\
\hline & \multirow{3}{*}{1.7 (2) } & & \\
\hline & & \multirow[t]{2}{*}{ ND } & \multirow[t]{2}{*}{ ND } \\
\hline & & & \\
\hline $\begin{array}{l}\text { Mobility } \\
(p H \text { 6.5) }\end{array}$ & -0.48 & 0.00 & 0.00 \\
\hline $\mathrm{N}$-terminal & Ser & Tyr & Tyr \\
\hline Yield & $6.5 \%$ & $22.4 \%$ & $14.0 \%$ \\
\hline Position & $165+182$ & $155 \rightarrow 164$ & $155 \div 164$ \\
\hline $\begin{array}{l}\text { Number of } \\
\text { residues }\end{array}$ & 18 & 10 & 10 \\
\hline $\begin{array}{l}\text { Procedure } \\
\text { of iso- } \\
\text { lation }\end{array}$ & $\begin{array}{l}P 4 ; 6.5 ; \\
C\end{array}$ & ${ }_{C}^{P} 4 ; 6.5 ;$ & $P 4 ; 6.5$ \\
\hline
\end{tabular}

Table 9M. Data on chymotryptic peptides of CB3T1j. For all details,

\begin{tabular}{|c|c|c|c|}
\hline $\begin{array}{l}\text { Amino } \\
\text { acid }\end{array}$ & CB3T $1 \mathrm{jCd}$ & CB3T1jCf & $\mathrm{CB} 3 \mathrm{~T} 1 \mathrm{jCh}$ \\
\hline $\begin{array}{l}\text { Lys } \\
\text { His } \\
\text { Arg }\end{array}$ & 0.8 (1) & 3.0 (3) & 1.1 (1) \\
\hline $\begin{array}{l}\text { ComCys } \\
\text { Asp } \\
\text { Thr }\end{array}$ & $0.9(1)$ & $\left.\begin{array}{ll}1.9 & \left\{\begin{array}{l}2 \\
1.5\end{array}\right. \\
2\end{array}\right\}$ & 0.8 (1) \\
\hline $\begin{array}{l}\text { Ser } \\
\text { Glu } \\
\text { Pro } \\
\text { Gly } \\
\text { Ala }\end{array}$ & $\begin{array}{l}3.2(3) \\
0.9(1)\end{array}$ & $\left.\begin{array}{ll}0.8 & (1 \\
1.9 & (2 \\
2.8 & (3)\end{array}\right)$ & $1.2(1)$ \\
\hline $\begin{array}{l}\text { Val } \\
\text { Ile } \\
\text { Leu } \\
\text { Tyr }\end{array}$ & $0.6(1)$ & $\left.\begin{array}{ll}0.7 & (1) \\
0.8 & (1 \\
0.7 & (1\end{array}\right)$ & \\
\hline $\begin{array}{l}\text { Phe } \\
\text { Trp } \\
\text { Hse }\end{array}$ & ND & ND & $0.9 .(1)$ \\
\hline $\begin{array}{l}\text { Mobility } \\
(\mathrm{pH} 6.5)\end{array}$ & 0.00 & +0.13 & +0.35 \\
\hline$N$-terminal & Val & Thr & Asn \\
\hline Yield & $6.9 \%$ & $26.9 \%$ & $13.4 \%$ \\
\hline Position & $197 \rightarrow 203$ & $181+196$ & $177+180$ \\
\hline $\begin{array}{l}\text { Number of } \\
\text { residues }\end{array}$ & 7 & 16 & 4 \\
\hline $\begin{array}{l}\text { Procedure } \\
\text { of iso- } \\
\text { lation }\end{array}$ & 6.5 & 6.5 & 6.5 \\
\hline
\end{tabular}

Table 10M. Data on chymotryptic peptides of CB4. For all detafls, see

\begin{tabular}{|c|c|c|}
\hline $\begin{array}{l}\text { Anino } \\
\text { acid }\end{array}$ & $C B 4 C b$ & $C B A C d$ \\
\hline Lys & $0.9\langle 1\rangle$ & \\
\hline His & & $0.9(1)$ \\
\hline & & $1.6(2)$ \\
\hline $\begin{array}{c}\text { CmCys } \\
\text { Asp }\end{array}$ & $2.2(2)$ & $\begin{array}{l}0.3 \\
3.0\end{array}\left(\begin{array}{l}1 \\
3\end{array}\right\}$ \\
\hline $\begin{array}{l}\text { Asp } \\
\text { Thr }\end{array}$ & $1.0\{1\}$ & $\left.\begin{array}{ll}3.0 & 3 \\
0.8 & 1\end{array}\right)$ \\
\hline Ser & 0.5 & $3.3\left\{\begin{array}{l}2 \\
3\end{array}\right.$ \\
\hline $\begin{array}{l}\text { Glu } \\
\text { Pro }\end{array}$ & 0.9 (1) & \\
\hline $\begin{array}{l}\text { Pro } \\
\text { Gly }\end{array}$ & $2.9\{3\}$ & $2.8 \quad(2)$ \\
\hline $\begin{array}{l}\text { Ala } \\
\text { Val }\end{array}$ & 1.1 (1) & $\left.\begin{array}{l}1.1 \\
2.0\end{array}\right\}$ \\
\hline $11 \mathrm{e}$ & 1.1 (i) & \\
\hline $\begin{array}{l}\text { Leu } \\
\text { Tyr }\end{array}$ & & \\
\hline $\begin{array}{l}\text { Tyr } \\
\text { phe }\end{array}$ & 0.7 (1) & \\
\hline $\begin{array}{l}\text { Trp } \\
\text { Hse }\end{array}$ & & $0.7 \quad(1)$ \\
\hline $\begin{array}{l}\text { Mobility } \\
\text { (pH 6.5) }\end{array}$ & 0.00 & +0.24 \\
\hline $\mathrm{N}$-termina 1 & Gly & $\operatorname{Arg}$ \\
\hline Yield & $40.5 \%$ & $36.0 \%$ \\
\hline Position & $126+136$ & $137 \rightarrow 154$ \\
\hline $\begin{array}{l}\text { Number of } \\
\text { residues }\end{array}$ & 11 & 18 \\
\hline $\begin{array}{l}\text { Procedure } \\
\text { of iso- } \\
\text { lation }\end{array}$ & 6.5 & 6.5 \\
\hline
\end{tabular}

Table 11M. Data on tryptic limited digest of the SPE-protein. For all

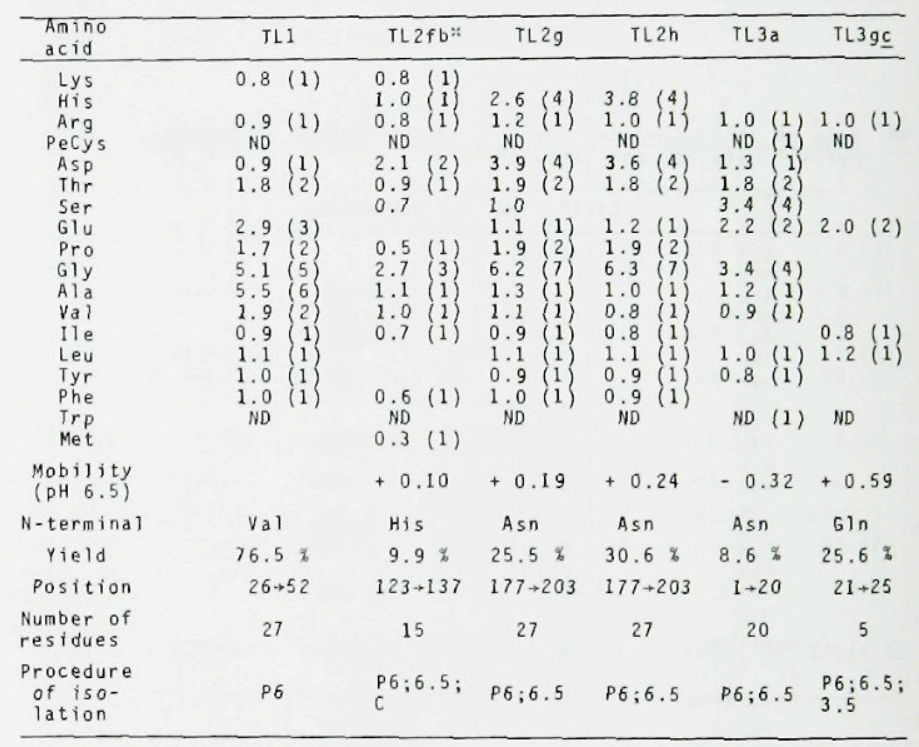


Table 12M. Data on tryptic peptides of $T L 1$. For all details, see Table

\begin{tabular}{|c|c|c|}
\hline $\begin{array}{l}\text { Amino } \\
\text { acid }\end{array}$ & rLITa & TL1TC \\
\hline $\begin{array}{l}\text { Lys } \\
\text { His }\end{array}$ & $1.0(1)$ & 0.3 \\
\hline $\begin{array}{l}\text { Arg } \\
\text { PeCys } \\
\text { Asp } \\
\text { Thr } \\
\text { Ser } \\
\text { nor }\end{array}$ & $\begin{array}{r}\text { ND } \\
1.3 \\
1.9 \\
1.2\end{array}$ & ${ }_{\text {No }}^{0,7}(1)$ \\
\hline $\begin{array}{l}\text { Glu } \\
\text { Pro }\end{array}$ & $\begin{array}{l}1.7 \\
2.0\end{array}\left\{\begin{array}{l}2 \\
2\end{array}\right\}$ & $1.0(1)$ \\
\hline $\begin{array}{l}\text { Gly } \\
\text { Ala } \\
\text { Ala }\end{array}$ & $\left.\left.\begin{array}{l}4.2 \\
4.1\end{array}\right\} \begin{array}{c}5 \\
1\end{array}\right\}$ & $\left.\begin{array}{l}0.6 \\
1.7\end{array} 2\right\}$ \\
\hline $\begin{array}{l}\text { Val } \\
\text { Ile }\end{array}$ & $\begin{array}{l}1.3 \\
1.2\end{array}\left(\begin{array}{l}1 \\
1\end{array}\right)$ & $0.9(1)$ \\
\hline $\begin{array}{l}\text { Leu } \\
\text { Tyr }\end{array}$ & $\begin{array}{l}0.7 \\
0.6\end{array}\left(\begin{array}{l}1 \\
1\end{array}\right)$ & \\
\hline $\begin{array}{l}\text { Phe } \\
\text { Trp }\end{array}$ & $\begin{array}{l}0.9 \\
\text { No }\end{array}$ & ND \\
\hline $\begin{array}{l}\text { Mobility } \\
(\mathrm{pH} \quad 6.5)\end{array}$ & 0.00 & +0.63 \\
\hline$N$-terminal & Val & Ala \\
\hline Yield & $40.0 \quad 2$ & $35.0 \%$ \\
\hline Position & $26 \div 47$ & $48 \div 52$ \\
\hline $\begin{array}{l}\text { Number of } \\
\text { residues }\end{array}$ & 22 & 5 \\
\hline $\begin{array}{l}\text { Procedure } \\
\text { of iso-- } \\
\text { lation }\end{array}$ & 6.5 & 6.5 \\
\hline
\end{tabular}

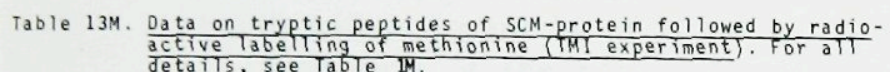

\begin{tabular}{|c|c|c|c|c|c|c|c|}
\hline $\begin{array}{l}\text { Amino } \\
\text { acid }\end{array}$ & $T M 13 \underline{c}$ & $T M I 3 q$ & TMI4 & $T M I 4 \underline{c}$ & TMI 5 $\underline{c}$ & TMI8b & $\operatorname{TM}[10,1$ \\
\hline $\begin{array}{l}\text { Lys } \\
\text { His }\end{array}$ & & 1.0 (1) & & 1.0 (1) & & & \\
\hline $\begin{array}{l}\text { His } \\
\text { Arg }\end{array}$ & 1.0 (1) & & & & & 2.5 (4) & 1.0 \\
\hline Carcys & 0.2 (1) & & 0.3 (1) & & & & 1.0 (1) \\
\hline Asp & & 2.2 (2) & & 1.9 (2) & & $3.7 \quad(4)$ & \\
\hline Thr & $1.9(2)$ & 0.7 (1) & & 0.9 (1) & & 1.7 (2) & \\
\hline Ser & 3.6 (4) & & 1.8 (2) & 1.2 (1) & $1.0 \quad(1)$ & & \\
\hline $\begin{array}{l}\text { Glu } \\
\text { Pro }\end{array}$ & $2.3(2)$ & $\begin{array}{l}0.4 \\
0.8 \quad \text { (1) }\end{array}$ & 1.1 (1) & $\begin{array}{ll}1.1 & (1) \\
0.9 & (1)\end{array}$ & $1.1(1)$ & $\begin{array}{ll}1.1 & (1) \\
1.7 & (2)\end{array}$ & 1.1 (1) \\
\hline Gly & 3.5 (4) & 2.5 (3) & $0.6(1)$ & $2.8(3)$ & 0.3 & $5.9(7)$ & \\
\hline $\begin{array}{l}\text { Ala } \\
\text { Val }\end{array}$ & $1.2(1)$ & $2.9(3)$ & 0.6 (1) & 4.1 (4) & 1.1 (1) & $1.2(1)$ & 1.1 (1) \\
\hline Ile & $1.0(1)$ & 0.9 (1) & 0.6 (1) & 0.9 (1) & & $0.9(1)$ & \\
\hline Leu & $1.1 \quad(1)$ & 0.9 (1) & & 0.9 (1) & & 0.9 (1) & 0.8 (1) \\
\hline $\begin{array}{l}\text { Tyr } \\
\text { Phe }\end{array}$ & 0.8 (1) & 0.8 (1) & 0.5 (1) & $\left.\begin{array}{ll}0.6 & 1 \\
1.8 & (2)\end{array}\right)$ & $\begin{array}{l}0.8 \\
1.0\end{array}\left(\begin{array}{l}1 \\
1\end{array}\right\}$ & $\left.\begin{array}{l}0.6 \\
1.0\end{array}(1\}\right)$ & \\
\hline $\begin{array}{l}\text { Trp } \\
\text { Met }\end{array}$ & ND (1) & ND & ND (1) & ND & ND & ND & $\begin{array}{l}\text { ND } \\
0.9(1)\end{array}$ \\
\hline $\begin{array}{l}\text { Mobility } \\
(\mathrm{pH} \\
6.5)\end{array}$ & ND & ND & ND & ND & ND & No & ND \\
\hline$N$-termina 1 & Asp & Gly & Phe & Phe & Phe & Asn & Leu \\
\hline Yield & $19.6 \%$ & $32.0 \%$ & $58.6 \%$ & $6.3 \%$ & $11.4 \%$ & $42.4 \%$ & $6.4 \%$ \\
\hline Position & $1 \rightarrow 20$ & $58 \rightarrow 71$ & $204 \rightarrow 212$ & $53 \rightarrow 71$ & $53 \div 57$ & $177 \rightarrow 203$ & $118+122$ \\
\hline $\begin{array}{l}\text { Number of } \\
\text { residues }\end{array}$ & 20 & 14 & 9 & 19 & 5 & 27 & 5 \\
\hline $\begin{array}{l}\text { Procedure } \\
\text { of iso- } \\
\text { lation }\end{array}$ & i: 3.5 & i; 3.5 & $i ; 3.5$ & $i ; 3.5$ & $i ; 3.5$ & $1 ; 3.5$ & $i ; i$ \\
\hline
\end{tabular}

Table 14M. Data on tryptic peptides of SCM-protein followed by radioactive labelling of met

\begin{tabular}{|c|c|c|c|}
\hline $\begin{array}{l}\text { Amino } \\
\text { acid }\end{array}$ & TMS1,2c & TMS2,2c & TMS2,2d \\
\hline $\begin{array}{l}\text { Lys } \\
\text { His }\end{array}$ & & $0.8(1)$ & \\
\hline Arg & $0.9\left(\begin{array}{l}1 \\
0.2\end{array}\right.$ & & 0.9 (1) \\
\hline $\begin{array}{l}\text { Asp } \\
\text { Thr }\end{array}$ & 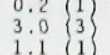 & $\left.\left.\begin{array}{l}1.1 \\
1.1\end{array}\right\} \begin{array}{l}1 \\
1\end{array}\right\}$ & \\
\hline $\begin{array}{l}\text { Ser } \\
\text { Glu }\end{array}$ & $3.1(4)$ & 0.3 & 1.1 (1) \\
\hline $\begin{array}{l}\text { Pro } \\
\text { Giy }\end{array}$ & $2.7 \quad(2)$ & 0.3 & \\
\hline $\begin{array}{l}\text { Ala } \\
\text { Val }\end{array}$ & $\begin{array}{l}1.0 \\
2.4\end{array}\left(\begin{array}{l}1 \\
2\end{array}\right)$ & $\begin{array}{l}1.9 \\
1.2\end{array}\left(\begin{array}{l}2 \\
1\end{array}\right\}$ & $1.0(1)$ \\
\hline $\begin{array}{l}\text { Ile } \\
\text { Leu } \\
\text { Tyr }\end{array}$ & & $0.9(1)$ & $0.7 \quad(1)$ \\
\hline $\begin{array}{l}\text { Phe } \\
\text { Trp } \\
\text { Met }\end{array}$ & No & $\begin{aligned} N 0 & \left(\begin{array}{l}1 \\
0.6 \\
1\end{array}\right)\end{aligned}$ & $\begin{array}{ll}100 \\
0.6\end{array}$ \\
\hline $\begin{array}{l}\text { Mobility } \\
(\mathrm{pH} 6.5)\end{array}$ & 0.00 & +0.29 & +0.40 \\
\hline W-terminal & Ser & Ala & Leu \\
\hline Yield & $7.2 \%$ & $4.0 \%$ & $10.6 \%$ \\
\hline Position & $138+152$ & $109+117$ & $118+122$ \\
\hline $\begin{array}{l}\text { Number of } \\
\text { residues }\end{array}$ & 15 & 9 & 5 \\
\hline $\begin{array}{l}\text { Procedure } \\
\text { of iso- } \\
\text { lation }\end{array}$ & $\begin{array}{l}P 6: 625 ; \\
6.5\end{array}$ & $\begin{array}{l}P 6 ; P 2 ; \\
6.5\end{array}$ & $\begin{array}{l}P 6 ; P 2 ; \\
6.5\end{array}$ \\
\hline
\end{tabular}

Table 15M. Data on peptic peptides containing cysteic acid. For all

\begin{tabular}{|c|c|c|c|c|c|c|}
\hline $\begin{array}{l}\text { Amino } \\
\text { acid }\end{array}$ & $\mathrm{Pa}$ & $\mathrm{Pb}$ & $\mathrm{PC}$ & $P d$ & Pea & Peb \\
\hline $\begin{array}{l}\text { Lys } \\
\text { His }\end{array}$ & & & & & & 0.5 (1) \\
\hline $\begin{array}{l}\text { Arg } \\
\text { Cy a a } \\
\text { Asp }\end{array}$ & $\left.\begin{array}{rr}0.8 & (1 \\
3.0 & 3 \\
2 & 3\end{array}\right)$ & $\left.\begin{array}{rl}1.0 & (1) \\
3.2 & (3)\end{array}\right)$ & $0.9(1)$ & $0.9(1)$ & $\left.\begin{array}{ll}1.1 & (1) \\
1.0 & (1) \\
3.2 & (3) \\
1.4 & (1)\end{array}\right)$ & $\begin{array}{ll}0.6 & (1) \\
0.5 & (1) \\
2.7 & (3) \\
0.6 & 11\end{array}$ \\
\hline $\begin{array}{l}\text { her } \\
\text { Ser } \\
\text { Glu }\end{array}$ & $1.2(1)$ & $1.1(1)$ & 0.7 (2) & $\begin{array}{l}0.5 \\
0.9\end{array}$ & $\begin{array}{l}1.4(1) \\
2.6 \\
0.6\end{array}$ & $\left.\begin{array}{l}0.6 \\
2.8(1) \\
0.4\end{array}\right\}$ \\
\hline $\begin{array}{l}\text { Pro } \\
\text { Gly }\end{array}$ & $0.5(1)$ & $0.5(1)$ & $\left.\begin{array}{ll}0.5 & (1 \\
0.7 & (1)\end{array}\right)$ & & $3.9(4)$ & 2.3 (2) \\
\hline $\begin{array}{l}\text { Ala } \\
\text { Val } \\
\text { Ile }\end{array}$ & $0.4(1)$ & $1.0(1)$ & $1.6\{1\}$ & $2.1(2)$ & $\left.\begin{array}{ll}0.8 \\
2.5 & 1 \\
2 & 2\end{array}\right)$ & $\left.\begin{array}{lll}1.5 & (2) \\
0.7 & 1\end{array}\right)$ \\
\hline $\begin{array}{l}\text { Leu } \\
\text { Tyr }\end{array}$ & & & & 1.1 (1) & 0.4 & \\
\hline $\begin{array}{l}\text { Phe } \\
\text { Trp } \\
\text { Met } 0_{2}\end{array}$ & ND & ${ }^{0} .5{ }^{5}(1)$ & $\begin{array}{cc}0.5 & \left(\begin{array}{l}1 \\
\text { ND } \\
1\end{array}\right)\end{array}$ & ${ }_{\text {NO }}^{0.4}(1)$ & ${ }_{\text {ND }}^{0.2}(1)$ & No (1) \\
\hline $\begin{array}{l}\text { Mobility } \\
(\mathrm{pH} 6.5)^{\mathrm{a}}\end{array}$ & -0.90 & -0.80 & -0.60 & -0.40 & 0.00 & 0.00 \\
\hline$N$-terminal & Asp & Asp & Phe & Phe & Gly & Asn \\
\hline Yield & $2.9 \%$ & $6.2 \%$ & $3.3 \%$ & $2.1 \%$ & $2.2 \mathrm{~g}$ & $1.7 \%$ \\
\hline Position & $78+84$ & $78+85$ & $204+211$ & $168+173$ & $134+150$ & $91+106$ \\
\hline $\begin{array}{l}\text { Number of } \\
\text { residues }\end{array}$ & 7 & 8 & 8 & 6 & 17 & 16 \\
\hline $\begin{array}{l}\text { Procedure } \\
\text { of iso- } \\
\text { lation }\end{array}$ & 6.50 & 6.50 & 6.50 & $6.5 \mathrm{D}$ & $\begin{array}{l}6.5 \mathrm{D} ; \\
3.5\end{array}$ & $\begin{array}{l}6.50 ; \\
3.5\end{array}$ \\
\hline
\end{tabular}

a) After performic oxidation. 
Copyright of European Journal of Biochemistry is the property of Blackwell Publishing Limited. The copyright in an individual article may be maintained by the author in certain cases. Content may not be copied or emailed to multiple sites or posted to a listserv without the copyright holder's express written permission. However, users may print, download, or email articles for individual use. 